This PDF is a selection from a published volume from the National Bureau of Economic Research

Volume Title: Capitalizing China

Volume Author/Editor: Joseph P. H. Fan and Randall Morck, editors

Volume Publisher: University of Chicago Press

Volume ISBN: 0-226-23724-9; 978-0-226-23724-4 (cloth)

Volume URL: http://www.nber.org/books/morc10-1

Conference Date: December 15-16, 2009

Publication Date: November 2012

Chapter Title: Assessing China's Top-Down Securities Markets

Chapter Author(s): William T. Allen, Han Shen

Chapter URL: http://www.nber.org/chapters/c12072

Chapter pages in book: (p. 149 - 195) 


\title{
Assessing China's Top-Down Securities Markets
}

\author{
William T. Allen and Han Shen
}

It is widely observed that, despite its remarkable economic progress over the last thirty years, the economy of China continues to require substantial development of its legal and financial infrastructure. In that connection, this essay seeks to assess an important part of that infrastructure: the securities markets of China. We assess those markets, both in terms of their size and composition and in terms of their economic function and importance to the Chinese economy. In doing so, we also review and assess the regulatory regime within which these markets function and the corporate governance mechanisms that operate upon the firms that are listed on the Chinese stock exchanges. For reasons of space, we do not review the history of the evolution of these markets (see Green 2003; Tan 2006), the corporatization program that created the firms that, for the most part, make up the listed firms on the two mainland exchanges (Aharony, Lee, and Wong 2000) or, except briefly, the original share segmentation system that restricted ownership of shares.

The Shanghai and Shenzhen Stock Exchanges represent an effort initiated

William T. Allen is director of the New York University Center for Law and Business, and professor of law on the law faculty and professor of business in the department of finance at the Stern School of Business, New York University. Han Shen is an associate at Davis Polk \& Wardwell LLP.

The authors wish to thank the editors of this volume, Justice Jack B. Jacobs of the Delaware Supreme Court, and Ms. Huang, Jie, NYU LL. M. 2005, for their very helpful comments on earlier drafts of this chapter and Ms. Gao, Yi, NYU LL. M. 2009, and Ms. Wei, Quiju, NYU LL. M. 2010, for their research assistance. The authors are responsible for the errors or omissions that remain. For acknowledgments, sources of research support, and disclosure of the authors' material financial relationships, if any, please see http://www.nber.org/chapters /c12072.ack. 
in the early 1990s to centralize and develop securities trading in modern China. Since that time those exchanges have grown rapidly in terms of listings, trading, products, and regulatory structures. They remain, however, a work in progress. While quite large by some measures, these markets do not yet play a very important role in the finance of the Chinese economy. The finance of the Chinese economy continues to be dominated, on large scale projects, primarily by bank finance and direct and indirect government support and, on entrepreneurial finance level, primarily by foreign direct investment and a range of less formal arrangements including friends and family, trade credit, business alliances and, importantly, local government support (Allen, Qian, and Qian 2005; Allen et al. 2013). The securities markets serve as a secondary source of finance to the Chinese economy. Access to the securities markets in China has been tightly controlled by the state and these markets have largely played the role of a supplemental source of finance for large state-owned enterprises (SOEs). The resulting markets are comparatively small in terms of the size of the general economy. Prices of securities traded on them are volatile and do not appear to price securities very well. Because prices on these markets do not appear to be efficiently set and because, as we show, the governance standards of the legal system they incorporate are ineffective, the market's prices do not provide either a positive signaling function or a disciplinary function for the corporate management of listed firms. Finally, because they have not yet evolved developed futures markets or a large capacity to create derivative securities, the Chinese securities markets do not yet provide adequate opportunities for the management of financial risks. For all of these reasons, the Chinese securities markets do not presently appear to deliver to the Chinese economy the principle allocative or disciplinary functions that a developed securities markets can provide.

If these markets do not provide the fundamental economic benefits that securities markets can provide, one may ask, why do they exist and grow? In this essay, we suggest that they flourish because they provide valuable benefits both to investors and to the Chinese state. Even without substantial legal system protection from exploitation, these markets do provide investors a way to participate in the rapid growth of Chinese economy. In addition, these markets provide the following significant benefits to the country and its leadership: (a) they provide a mechanism through which foreign capital can flow to support the SOEs that comprise the largest part of the firms listed on the mainland exchanges; (b) they provide a channel through which can flow a limited amount of investment from the very large reservoir of domestic savings in order to do the same thing; (c) they serve as means to induce improvements in the management and governance of listed SOEs; (d) they provide to the leadership a possible option for future expansion of the role of private sector in financing enterprise, including both the exist- 
ing state sector and the entrepreneurial sector of the economy; and finally (e) they provide in some measures the noneconomic satisfaction of locating a globally important center of finance on mainland China.

Thus, despite the limited economic importance of Chinese securities markets to the nation's economy at the moment, they continue to command both international investors' interest and the support of the country's leadership. The leadership has demonstrated its continuing commitment to building out the infrastructure that might allow Chinese securities markets to play a greater role in the future in its extended effort to restructure the Chinese share segmentation system (see section 3.1.1) and in facilitating the continued development of instruments of modern finance (see section 3.1.4). The following essay aims to assist readers who are interested in thinking about the future of these markets.

In section 3.1 we provide a descriptive report on the current state of the Chinese securities markets, discussing their place in the national system of finance, their current size and scope, their interesting relationship to the Hong Kong securities market, and the gradual development of new tools of securities investing in China. In section 3.2 we discuss the current regulatory environment of these markets, focusing on the structure and operation of the Chinese Securities Regulatory Commission (CSRC), which has a powerful role in controlling these markets, access to listing shares on them, and supervision of all the institutional actors on them. In section 3.3 we discuss the corporate governance of listed firms, including both the formal or legal system of corporate governance and, more importantly, the role of the Chinese Communist Party in the internal affairs of listed companies. In section 3.4 we conclude with observations concerning the fundamental contradiction between the Chinese securities markets' top-down design and control on the one hand and, on the other hand, their possible effectiveness in efficient capital allocation, in risk management and as a tool of discipline. We discuss the factors that may someday weigh on the perceived need of the leadership to address this contradiction.

\subsection{The Characteristics of the Chinese Securities Markets Today}

The Chinese securities markets constitute an impressive accomplishment. The technological, legal, and human infrastructure supporting these markets has been created from almost nothing two decades ago. While they remain a work in progress, that progress has been remarkable.

In assessing these markets, we begin by placing them in context of the formal system that finances business activities in China today. China's system of formal finance is essentially a bank-centered system primarily dominated by its four largest state-owned banks. China's economy has a substantially higher ratio of bank credit to GDP (1.27 at the close of 2009 according to 
the National Bureau of Statistic of China), than even the German, bankcentered system of finance (.99). Securities markets by comparison, while large by some measures, are small in economic terms. Moreover, when assessing the reported size of these markets, it is important to understand that what actually trades on the mainland exchanges (and in fact what, until quite recently was legally tradable on them) is in almost all cases a very small percent of the outstanding shares (see e.g., the analysis of the holdings of the shares in the Industrial and Commercial Bank of China (ICBC), China's largest bank, reported in section 1.3).

Expressed in terms of proportion of financial assets rather than percentage of GDP, data for 2006, confirms the relatively undeveloped state of the mainland securities markets. According to CSRC data for that year, the total value of securities in the PRC (equities and bonds, including treasury bonds) constituted just 22 percent of total financial assets, while in the United States, United Kingdom, Japan, and Korea those percentages were far higher ( 82 percent, 71 percent, 62 percent, and 75 percent, respectively) (CSRC Report, 2008, 237). Data compiled by McKinsey \& Company for year 2008 reported in figure 3.1 is consistent with this view. China appears on this data to have a substantially higher proportion of financial assets in bank deposits than any other region. Moreover, this figure most probably exaggerates the importance of securities markets in China by using market capitalization data without adjusting for the very thin float of listed firms, which we discuss later.

As we noted, an accurate understanding of the scale and scope of the Chinese securities markets must consider the ongoing effects of the now reformed share segmentation system that until recently limited the number of shares of each listed SOE that could be traded on an exchange. Therefore, we begin our discussion of the markets with a brief description of that reform. Those familiar with the well-known share segmentation system and its now largely completed reform may safely move directly to section 3.1.2.

\subsubsection{Background: The Share Segmentation System and Its Reform}

Among the signal marks of the program of liberalization that was initiated in 1978 under the leadership of Deng Xiaoping was its pragmatism and gradualism. Among the steps taken to ensure that corportization of certain state sector production facilities could be safely tried, while not engendering unforeseen complication, was the adoption of a plan strictly to limit the potential nonstate ownership of shares of the corporations that were to be formed from state and province production facilities. Thus newly incorporated enterprises carved from state assets in the 1990s were authorized by the State Council to issue shares pursuant to an elaborate share segmentation plan.

Under the share segmentation scheme that governed the listing of shares on securities exchanges, a majority of shares of SOEs (which from the begin- 


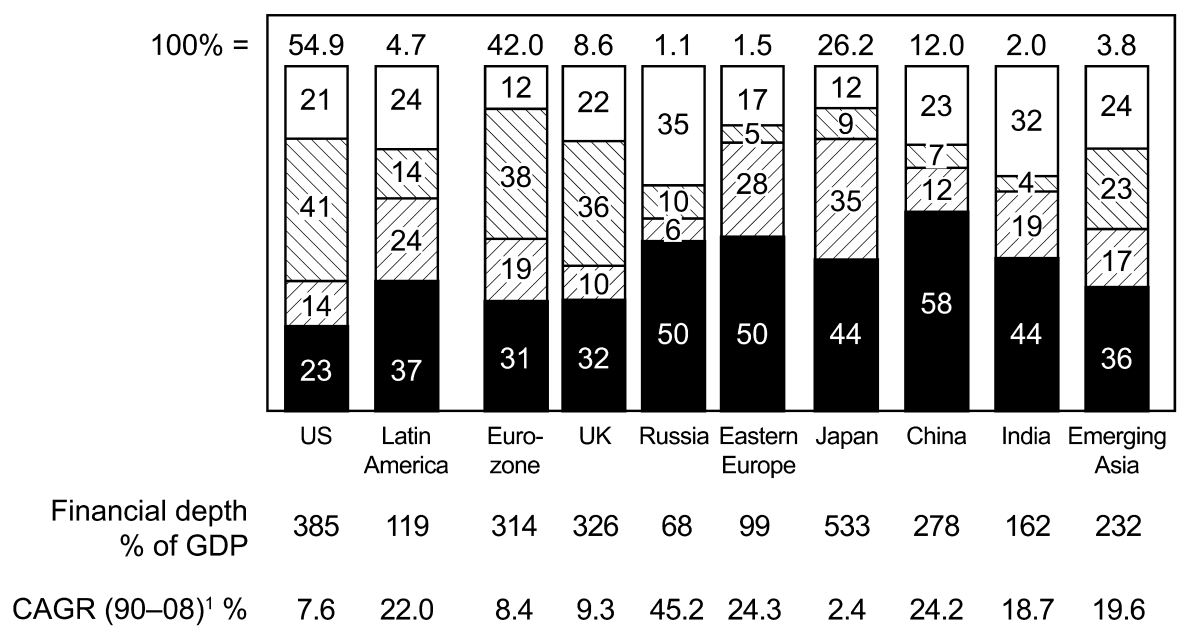

$\square$ Equity securities $\quad \square$ Government debt securities
$\square$ Private debt securities
Bank deposits

Fig. 3.1 Financial assets by region, 2008 (\$ trillion, \%)

Source: McKinsey Global Institute Global Financial Stock database.

Note: Some numbers do not sum due to rounding.

${ }^{1}$ Compound annual growth rate using 2008 exchange rates.

ning and today constitute most of the companies listed on the exchanges) would be nontradable and held by institutions that were directly or indirectly controlled by the government. The minority of shares that were to be tradable were themselves broken down into A shares and B shares on both Shanghai Stock Exchange and Shenzhen Stock Exchange. The A shares constitute the vast majority of shares traded on these exchanges, are traded in renminbi on the Shanghai or Shenzhen stock exchanges, and originally could be purchased only by Chinese nationals or institutions. The B shares are traded on the same exchanges but were listed in US dollars in Shanghai and Hong Kong dollars in Shenzhen; they could be purchased originally only by foreign nationals or institutions (now they can be purchased by Chinese nationals as well). ${ }^{1}$ In addition to A and B shares, some larger Chinese firms, seeking access to foreign capital, have received (from the CSRC)

1. The B share prices traded at prices below the same shares trading in A shares. But when Chinese nationals were given access to the B share market, the arbitration then eliminated the price differences. 
permission to list on foreign exchanges. Stocks traded on these exchanges are denominated $\mathrm{H}$ shares (Hong Kong Stock Exchange), N shares (New York Stock Exchange [NYSE]), L shares (London Stock Exchange [LSE]), and $\mathrm{S}$ shares (Singapore Exchange) and carry the same voting and cash flow rights as A shares.

Importantly, in addition to the segmentation of shares into A and B shares, Chinese shares were distinguished by the nature of the holder. Shares could be either (1) pre-IPO (initial public offering) shares issued in connection with the "corporitization" of the assets to (a) instrumentalities of the statesuch as a Ministry, the State-owned Assets Supervision and Administration Commission (SASAC), or provincial or municipal governments - or (b) to certain legal persons (principally the parent of the listed SOE, which itself will generally be controlled by a provincial or municipal body); or (2) shares issued in or after the IPO to Chinese nationals or institutions (for example, the Qualified Foreign Institutional Investors, or QFIIs). At least prior to the recent reform described below, the pre-IPO shares issued to state or municipal entities or to SOE management as part of the IPO process were generally classified as "C shares" and were not tradable on the exchange. Nontradable shares (NTSs) could only be transferred to legal persons (including in recent years foreign strategic investors) in private placements with the prior approval of both SASAC and the CSRC.

Prior to the completion of share segmentation reform, significantly, with respect to every listed SOE - and most of the firms listed on the Shanghai Stock Exchange are SOEs, recent estimates varying between 70 percent and 80 percent (Chen, Firth, and Xu 2009) - NTSs significantly outnumbered the proportion of shares that are tradable. According to CSRC data, for example, at the end of 2004, there were 714.9 billion shares outstanding of all listed Chinese companies, of which 454.3 billion or 64 percent were nontradable. Thus, a fact of fundamental importance is that the trading market on the Chinese securities exchanges has represented only minority interests. Generally for most listed firms control exists in one or more state affiliated firms or entities. For a relatively small minority of listed firms control exists in an individual, family, or small group.

The nontradability of control blocks has been deemed undesirable and the CSRC attempted for several years to reform this structure. After several failed attempts to do so, the CSRC has now largely completed its program in which most NTSs have been converted to shares that may be traded on the exchanges. The state-owned shares are now legally capable of being gradually floated to the open market according to relevant rules. ${ }^{2}$

2. Article 27 of "The Administrative Measure of Share Segmentation Reform of Listed Companies" issued by the CSRC in September 2005 requires that (1) the NTSs cannot be publicly traded or transferred within twelve months after the implementation of the reform proposal of NTSs adopted by the listed company; (2) with regards to these NTSs shareholders who own more than 5 percent shares of a listed company, after the expiration of the above required 
However, the completion of the share segmentation reform raises a new series of economically interesting questions. Will the state in fact dissolve its control blocks through secondary market sales of formerly NTSs? If so, the control of which firms will be put on the market and when? It seems highly unlikely that the state will allow control over key elements of the economy (e.g., finance, transportation, energy, communications, and natural resources) to pass into the market. And with respect to less vital SOEs, the state may raise capital by sale of state-owned shares while retaining blocks of 20 to 25 percent, which ordinarily would be deemed sufficient to thwart a market based change in corporate control.

Thus while the completion of the NTSs reform removes a formidable impediment to the development of an effective securities market, it remains to be seen if, when, and with respect to which firms the reform will be operationalized.

\subsubsection{Growth in Market for Large Company (SOEs) Shares}

The Chinese stock exchanges are now quite large. By close of June 2010, the Shanghai and Shenzhen Stock Exchanges together listed 1,891 companies. The majority listed companies were SOEs. ${ }^{3}$ Using the market capitalization metric, with its weaknesses, the two mainland Chinese exchanges would have together constituted the fourth-largest exchange in the world at the close of June 2010. At that time, the total market capitalization of both markets equaled US\$2,877.6 trillion, about one-quarter of the size of the NYSE. While in the context of the Chinese securities markets, market capitalization figures may mislead as much as inform, still the numbers are impressive. Daily trading volume on both markets averaged US $\$ 33.4$ billion as of April 30, 2010. ${ }^{4}$ Again, measured in total market capitalization, the comparative growth rates of these exchanges and their volatility appears remarkable. Comparative data for the periods of 2006 through 2009 are set forth in table 3.1.

In recent years, the mainland exchanges have been active sites for raising new capital. Indeed, according to data collected by the World Federation

twelve-month period, they are not allowed to sell more than 5 percent of shares converted from NTSs on a stock exchange within twelve months and are not allowed to sell more than 10 percent of shares converted from NTSs within twenty-four months.

3. As of 2000, Tam (2002) put the number at 90 percent Liu and Sun (2003) put the number at 84 percent. See Clarke (2008). One study looked at the period of 1999 to 2004, consisting of 6,113 samples, and it concluded that the state directly and indirectly acted as major controlling shareholder at 79.7 percent of firms. See Chen, Firth, and Xu (2009). As of the end of 2007, it appeared that 65 percent of these listing were SOEs (and essentially all of the largest firms). In 2006 there were fourteen new listings on the Shanghai Exchange, all of which were SOEs.

4. The Shanghai Stock Exchange Composite Index, which has a base (1991) value of 100, started 2006 at less than 1,500. It peaked at 6,124.0 in October 2007 and then began to decline steeply. It dipped below 2,000 in late 2008 and then began to recover. By early 2010 it stood at slightly more than 3,000 and then it dropped to around 2,300 by the end of June 2010 . 


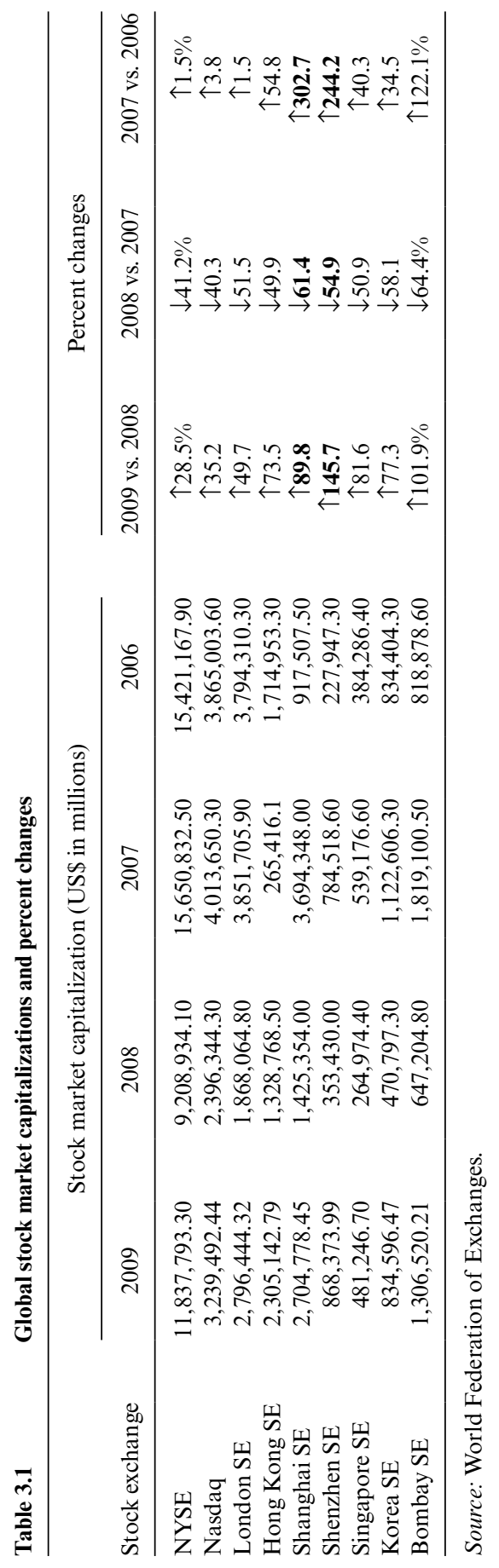


Table 3.2

Market capitalization of newly listed shares (US\$ in millions)

\begin{tabular}{lrrrrrr}
\hline & \multicolumn{1}{c}{2004} & \multicolumn{1}{c}{2005} & \multicolumn{1}{c}{2006} & \multicolumn{1}{c}{2007} & 2008 & 2009 \\
\hline Shanghai SE & 14,438 & 3,140 & 223,322 & $1,576,732$ & 92,118 & 99,924 \\
Shenzhen SE & 8,536 & 1,634 & 23,691 & 74,655 & 38,769 & 71,450 \\
Hongkong SE & 37,347 & 98,292 & 102,941 & 155,199 & 28,767 & 95,235 \\
NYSE & 118,944 & 135,719 & 192,412 & 244,515 & 207,612 & 64,810 \\
LSE & 52,468 & 322,269 & 131,137 & 144,674 & 77,560 & 24,437 \\
Tokyo SE & 87,832 & 110,399 & 81,982 & 35,969 & 40,106 & 18,062 \\
\hline
\end{tabular}

Source: World Federation of Exchanges.

Table 3.3 Market concentration, percentages of total market capitization represented by largest ten firms

\begin{tabular}{lcccccc}
\hline & $\begin{array}{c}2004 \\
(\%)\end{array}$ & $\begin{array}{c}2005 \\
(\%)\end{array}$ & $\begin{array}{c}2006 \\
(\%)\end{array}$ & $\begin{array}{c}2007 \\
(\%)\end{array}$ & $\begin{array}{c}2008 \\
(\%)\end{array}$ & $\begin{array}{c}2009 \\
(\%)\end{array}$ \\
\hline NYSE & 19.6 & 16.4 & 16.1 & 19.3 & 20.1 & 15.7 \\
London SE & 40.2 & 40.9 & 37.1 & 38.2 & 46.3 & 41.3 \\
Shanghai SE & 29.0 & 32.6 & 56.6 & 51.6 & 49.0 & 41.2 \\
Tokyo SE & 18.1 & 18.1 & 20.1 & 18.5 & 18.3 & 17.6 \\
\hline
\end{tabular}

Source: World Federal of Exchanges.

of Exchanges, the Shanghai Stock Exchange raised more capital during the period of 2006 to 2009 than any other global market (see table 3.2).

\subsubsection{Concentration, Liquidity, and Pricing Efficiency of the Shanghai Stock Exchange}

The largest SOEs dominate trading on the Shanghai Stock Exchange. Of more than 800 listed firms as of June 2010, the ten largest firms represent 39.5 percent of the exchange's total market capitalization. The two largest listed firms, PetroChina Company Limited ("PetroChina") and Industrial and Commercial Bank of China ("ICBC"), together account for approximately 20 percent of the market capitalization of the entire exchange as of June 2010. ${ }^{5}$ The Shanghai Stock Exchange is substantially more concentrated than either the New York Stock Exchange or the Tokyo Exchange, but about the same as the London Stock Exchange (see table 3.3) in 2009.

As we suggested earlier, market capitization figures of the Chinese exchanges must be interpreted carefully because of the large blocks of untraded (albeit now legally tradable) shares in virtually every listed firm.

5. The equity market cap of PetroChina and ICBC accounted for 11.93 percent and 7.33 percent, respectively, of the market capitalization of the entire Shanghai Stock Exchange as of June 30, 2010 (Shanghai Stock Exchange Statistics). 


\begin{tabular}{lllcc}
\hline Name of shareholder & $\begin{array}{c}\text { Nature of } \\
\text { shareholder }\end{array}$ & $\begin{array}{c}\text { Type of } \\
\text { shares }\end{array}$ & $\begin{array}{c}\text { Total number } \\
\text { of shares held }\end{array}$ & $\begin{array}{c}\text { Shareholding } \\
\text { percentage } \\
(\%)\end{array}$ \\
\hline $\begin{array}{c}\text { Central Huijin } \\
\text { Investment Limited }\end{array}$ & State-owned & A shares & $118,316,816,139$ & 35.4 \\
$\begin{array}{c}\text { Ministry of Finance of } \\
\text { the PRC }\end{array}$ & $\begin{array}{c}\text { State-owned } \\
\text { Foreign } \\
\text { corporation }\end{array}$ & A shares & $118,006,174,032$ & 35.3 \\
$\begin{array}{c}\text { HKSCC Nominees } \\
\text { Limited }\end{array}$ & H shares & $68,577,667,687$ & 20.5 \\
$\begin{array}{c}\text { The Goldman Sachs } \\
\text { Group, Inc. }\end{array}$ & $\begin{array}{c}\text { Foreign } \\
\text { corporation }\end{array}$ & H shares & $13,180,811,324$ & 3.9 \\
$\begin{array}{c}\text { American Express } \\
\text { Company }\end{array}$ & $\begin{array}{c}\text { Foreign } \\
\text { corporation }\end{array}$ & H shares & $638,061,117$ & 0.2 \\
\hline
\end{tabular}

${ }^{a}$ Central Huijin Investment Limited is a wholly owned subsidiary of China Investment Corporation, the Chinese state sovereign investment company.

${ }^{\mathrm{b}}$ Most retail and institutional investors hold their shares through a bank, broker, or custodian who in turn hold them in an account with the Central Clearing and Automated Settlement System (CCASS) operated by Hong Kong Securities Clearing Co., Ltd. (HKSCC), a subsidiary of HKEx. HKSCC Nominees Ltd., a subsidiary of HKSCC, is the registered shareholder of listed companies and acts as nominee for the account holders of CCASS. The total number of shares held by HKSCC also included $\mathrm{H}$ shares held by PRC National Council for Social Security Fund.

Consider, for example, the share ownership structure of ICBC, the secondlargest market cap listing on the Shanghai Stock Exchange. In October 2006, ICBC, the state-owned bank, simultaneously listed and distributed a minority block of its shares on the Shanghai Stock Exchange and the Hong Kong Stock Exchange, in what proved at the time to be the world's largest IPO, generating approximately US $\$ 21.9$ billion in proceeds.

As of June 30, 2010, ICBC had more than 334 billion shares outstanding; 24.87 percent of its outstanding shares were $\mathrm{H}$ shares listed and traded on the Hong Kong Stock Exchange. The remainder of its shares, following the completion of share segmentation reform were A shares technically tradable on the Shanghai Stock Exchange. But how much of this equity was actually public floated and controlled by nonstate affiliate entities? Table 3.4 sets forth shareholding of the top five shareholders of ICBC as of June 30, $2010 .^{6}$

From the table, we conclude the publicly owned ICBC shares tradable on the Shanghai Stock Exchange constitute less than 4.3 percent of ICBC A shares (since most of the 75.13 percent of ICBC shares that could in theory be traded on the Shanghai Stock Exchange are actually held by Central Huijin Investment Limited or the Ministry of Finance). One must look to the Hong Kong Stock Exchange to find more substantial private investment 
in ICBC shares. ${ }^{7}$ There we find listed ICBC $\mathrm{H}$ shares constitute 24.87 percent of all outstanding ICBC shares. One obvious conclusion from these figures is that in the case of ICBC, the Hong Kong Stock Exchange has been much more important than Shanghai as a source of new capital. Specifically, more than six times the capital raised by ICBC from investors on the Shanghai Exchange was raised by it on the Hong Kong Stock Exchange.

The ICBC's share trading structure is not unique among the largest SOEs. The proportion of shares not controlled by state-affiliated entities of the largest firms on the Shanghai Stock Exchange is typically quite small. For example, as of June 30, 2010, 67.53 percent of the A shares of Bank of China were owned by Central Huijin Investment Ltd. and less than 2.35 percent A shares were publicly floated and controlled by domestic non-state-owned entities or individuals. ${ }^{8}$

Notably, the same cash flow rights usually command a somewhat higher price on the Shanghai Stock Exchange than on the Hong Kong Stock Exchange. This mainland premium is chiefly due, we believe, to impediments to low cost arbitrage between mainland markets and the Hong Kong market and to the huge demand for investment that the high personal or family savings rate in China generates. The Hang Seng China A-H Premium Index, launched on July 9, 2007, tracks the average price difference between A shares and $\mathrm{H}$ shares for the largest and most liquid China enterprises with both A-share and H-share listings. The Hang Seng China A-H Premium Index reached a high at 208 in January 2008, meaning A shares are trading at an average premium of 108 percent above $\mathrm{H}$ shares and the index for the first half of 2010 was generally between 100 to 120 percent. Greater opportunities for arbitrage between these markets will, of course, reduce or eliminate this difference.

The upshot of the fact that the trading markets in Shanghai are relatively thin and are more highly concentrated than most developed markets and that Chinese investors have highly restricted alternative investment opportunities, is that there is a good reason to suppose that the prices reflected on the mainland markets are not a good signal of fundamental value of the shares or the firms listed on the exchange. In fact, Chinese stock markets are frequently described as highly volatile; price movements are notably synchronous (e.g., Morck, Yeung, and Yu 2000; Xie, Dai, and Xu 2003) and when market prices are compared to prices at which control transactions occur it has been found that the control of a listed firm is traded by private

7. Chinese companies form a substantial part of the market capitalization of the Hong Kong Stock Exchange. As reported by the Hong Kong Stock Exchange, by the end of June 30, 2010, the market capitalization of China-related stocks on its main board reached 48.54 percent of the market capitalization.

8. As of June 30, 2010, 70 percent of the issued shares of Bank of China were A shares. 67.53 percent of the A shares of Bank of China were owned by Central Huijin Investment Ltd., and China Southern Power Grid Co., Ltd., Aluminum Corporation of China, and Shenhua Group Corporation Limited each held 0.04 percent. 
contract on average at almost a 20 percent discount to market price (Tuan et al. 2007). The reasonable conclusion is that traded prices are likely not a good signal of fundamental firm value.

\subsubsection{Product Innovation: Short Sales, Margin Sales, and Indexed Futures}

The securities markets in China have yet to develop a range of investment tools that are used elsewhere for investor risk management and which tend to reduce market volatility. These tools include short selling, margin buying, and equity futures contracts. In recent years, however, steps have been going forward to carefully introduce these investment techniques. In 2007, the State Council, after long study, approved regulations formally permitting trade in financial futures and options. The Chinese Financial Futures Exchange (CFFEx) was then formed under the authority of the CSRC. The CFFEx spent the following years building an electronic platform for futures trading and a comprehensive set of procedures to facilitate trading by brokers and discourage retail participation in a possible futures market. ${ }^{9}$ It was not until January 2010, however, that the State Council approved a trial period for the introduction of these investment tools.

Caution was also reflected in the introduction of short sales of equities and margin trading in January 2010. Regulatory restrictions have been designed to control the effects of these innovations. For example, only selected securities firms will be authorized to execute short sales or margin sales and they must use their own capital and shares to effect these transactions. Thus, it is expected that no market in borrowed shares for the purpose of short sales will develop for the present at least. These restrictions will limit the use of these techniques and should be seen as an attempt to introduce these techniques in a guarded way.

The inability to sell shares short or to buy or sell futures in securities has starkly limited the ability of Chinese institutional investors to hedge financial risk and has likely contributed to excessive market volatility of the Chinese markets. No doubt the financial market turbulence during the period 2008 to 2009 made that period seem an inauspicious time in which to implement these desirable securities market innovations. It is a sign both of the confidence of the leadership in the Chinese economy and their serious desire to build out the Chinese securities markets as large modern securities markets, that these changes were kick-started again in January 2010.

\subsubsection{Institutional Investors}

Retail investors dominated China's stock markets from their inception.

9. Thus draft regulations established a minimum 10 percent margin requirement and a price for a single contract, at current price levels of the Shanghai-Shenzhen 300 Index (January 2010) of approximately RMB 100,000. 
This fact has doubtlessly contributed to the relative price volatility of these markets. The dominance of retail investors, however, has gradually eroded in China, as QFIIs and domestic institutional investors, such as insurance companies, a variety of managed investment funds, and the national social security fund have grown in importance. In fact, by the end of 2008, the CSRC could report that institutional investors had for the first time became the dominant force in the market, by holding 54.6 percent of market capitalization of all tradable shares in the domestic markets. ${ }^{10}$ By comparison, we note that institutional investors have been reported to represent 70 percent of the Hong Kong Stock Exchange and 80 percent of the New York Stock Exchange.

The participation of QFIIs in the two mainland exchanges, however, remains quite limited. These foreign institutional investors would no doubt be interested in channeling increasing amounts of foreign investment into the Chinese securities markets. But their ability to do so is limited. Following the initiation of the QFII program in 2003, qualifying institutions were permitted to invest in the A share and the government bond markets. According to the State Administration of Foreign Exchange, as of June 30, 2010, there were eighty-eight QFIIs approved in China, with an approved investment amount of US\$17.1 billion. ${ }^{11}$ As a percentage of market capitalization of trading volumes in the A share market, this quota represents only about 2.5 percent of former "A shares" and of course a much smaller proportion of postmarket reform potential market capitalization.

A Chinese institutional investor deserving mention in this connection is the National Council for Social Security Funds (NSSF), established in 2000. The NSSF is responsible for the investment of funds to support a future retirement system. The investment fund it manages comes from central government budget allocations, from investment returns it can earn, and from liquidation of state-owned shares in SOEs. That is, in order to help fund future pension system needs, the Chinese government has required that in connection with any share sale by one of 131 SOEs, that the NSSF be funded with 10 percent of the proceeds of such sales up to the limit of the state's holding in the company. At the end of 2009, NSSF managed total assets of RMB 562.4 billion.

\subsubsection{Market Access for "Private" Firms: The SME Board and the GEM Board}

To a large extent, the growth of the Chinese economy is attributable not to the SOEs that dominate the Shanghai Stock Exchange, but to private

10. See CSRC 2008 Annual Report available from http://www.csrc.gov.cn/pub/newsite/zjhjs /zjhnb/200906/P020090630327035004673.pdf, at 19.

11. See data from State Administration of Foreign Exchange, available from http://www.safe .gov.cn/model_safe/glxx/glxx_detail.jsp?ID=120700000000000000. 
and hybrid firms; that is, those firms with private as well as local government involvement (as lenders, minority owners, or business partners). But formal sources of finance-either bank loans or securities marketsare difficult for private firms in China (Shen et al. 2009). These firms have largely, but not completely, been excluded by the CSRC from listing on the stock exchanges. While there are about 570 private companies listed on the two Chinese stock exchanges, representing 34.8 percent of the total number of all listed companies, those firms represent only 12.2 percent of the market capitalization (Shanghai Stock Exchange, August 10, 2009).

Private firms have tended not to be approved for listing by the CSRC for a variety of reasons. First, of course, is the fact that the fundamental mission of the securities markets, at least for the first fifteen years of their existence, has been to support SOEs with additional capital. Especially in the first years of the exchanges, allocation of listings were heavily influenced by the capital needs of inefficient provincial level SOEs. Second, the CSRC deems itself charged to protect investors from excessively risky companies. Thus an unwillingness to approve listings for private firms may, in part, reflect a belief that these firms will on average be more risky than existing state-affiliated enterprises. Third, these smaller more entrepreneurial enterprises may lack political patrons, which in a system (and a culture) that is inevitably affected by political and personal networks, may be a significant disadvantage. Finally, the underrepresentation of small and growing private firms may in part reflect an ideological bias against "private" wealth building. Whatever the source of the bias, given the fact that, as a class, private or hybrid firms represent the greatest prospect for substantial economic growth, the failure of the securities markets to provide finance to this segment must be deemed as a substantial current weakness. The leadership has recognized this fact and approved substantial steps to address it. The CSRC has two initiatives in that respect. In 2004, a Small and Medium Enterprises Board (the "SME Board") was opened in Shenzhen Stock Exchange and more recently a Growth Enterprise Board ("GEB Board") was opened on the same exchange.

The SME Board has met with some success. Private enterprises have a very significant presence on the SME Board. They are said to represent approximately 76 percent of listed companies as of October 2005 (Zhang 2005). By June 2010, 437 firms had listed shares on this board. Moreover, reportedly the annual average revenue growth rate of these firms was 30 percent and growth rate of net profit was reportedly 18.5 percent. ${ }^{12}$ However, in many respects the listing standards for the SME Board are similar to those of the bigger boards. The SME Board requires companies to have a minimum RMB 30 million of accumulated net profits in the three recent years prior

12. China Global Times, March 25, 2010. http://china.globaltimes.cn/editor-picks/2009-05 /432813.html 
to listing. This rather importantly limits its utility to smaller entrepreneurial firms.

The CSRC's second, more recent and more substantial step to try to begin to afford better access to capital markets to nonstate enterprises was reflected in the first IPO in October 2009 on the new GEB Board, also sometimes referred to as "ChiNext," of the Shenzhen Stock Exchange. This board has been designed to function much as the NASDAQ market does in the United States, providing public capital to entrepreneurial, especially hightech firms. One aspect of this initiative is to provide a potential exit channel for venture capital funded enterprises, thus further encouraging the development of a PRC venture capital business. Access to the GEB Board will be overseen by a special review committee, which will presumably be professionally familiar with the special character of entrepreneurial and venture financed firms. The standards for listing on the GEB Board are lower than those of the SME Board: a minimum RMB 10 million in retained earnings. ${ }^{13}$ Nevertheless, in contrast to similar markets in other countries, companies that apply for the listing on the GEB Board must already be profitable, a test that neither Amazon nor Ebay, for example, would have been able to satisfy. Thus, even these innovative small company boards may reflect a strong regulatory bias against more risky enterprises. This bias may be appropriate in a system with a weak information environment, but it does limit the benefits that entrepreneurial activity can provide.

The first batch of twenty-eight selected firms for listing on the GEB Board went public on October 30, 2009 to warm market acceptance. ${ }^{14}$ As of June 2010, ninety companies were listed on the GEB Board.

\subsubsection{The Absence of a Substantial Market for Commercial Bonds}

From the perspective of more highly developed financial markets, a notable feature of the Chinese securities markets, is the practical absence of a market for commercial bonds and indeed a very small bond market even when government bonds are included.

For example, at the close of 2006, the PRC bond market was reported to equal just 35.3 percent of China's GDP. Comparable international bond market numbers demonstrate the undeveloped nature of the Chinese bond market: Japan (201.0 percent), the United States (188.5 percent), United Kingdom (140.5 percent), Korea (125.1 percent), and Germany (69.0 percent) (CSRC Report, 245). The existing bond market is heavily dominated by treasury bonds and financial institutions bonds. Huang and Zhu report that there are primarily four types of bonds in the domestic Chinese bond

13. See C. Guan and S. Li, Preliminary Comparison between ChiNext and SME, http://www .chinalawandpractice.com/Article/2351745/Channel/9846/Preliminary-comparison-between -ChiNext-and-SME.html.

14. According to Caijing (October 26, 2009), a total of 188 companies applied to list on the GEB and about 70 percent of the applicants are from the electronics, new materials, alternative energy, biomedicine, and other emerging sectors. 
markets: Treasury bonds (they estimate at RMB 2,149 billion in late 2006), central bank notes (RMB 2,931 billion), financial bonds (RMB 2.097 billion), and commercial bonds (RMB 170 billion). Thus the bond market supplies only a tiny portion of the capital available to nonfinancial firms. The CSRC gives somewhat different estimates but the proportions are about the same. It estimates treasury bonds at 53.3 percent of the market and bonds of government-owned financial institutions at 37 percent at the end of 2007 (CSRC Report, 246). The CSRC reports that only 4.2 percent of the small PRC bond market represents what it classifies as "corporate bonds," and most of that amount represents the small short-term commercial paper market at 3.7 percent. Reportedly, only .05 percent of the bond market represents bonds issued by listed companies. When coupled with the very limited ability to hedge equity investments through derivative or futures trading, one can see the job of insurance company investment managers as very challenging in China.

China's lack of a substantial bond market does not make it an outlier among developing nations, however. As figure 3.1 shows, India and Russia both have small bond markets. But neither of these countries has developed their economy or the formal institutions of capital markets as consistently as has China. Therefore, one is entitled to wonder why this aspect of capital market development has not made more progress in China? A possible answer might involve a desire to protect the large state-owned banks from bond or money market competition. Should a substantial bond market be available for long- or short-term debt, presumably the strongest credits would tend to migrate there, leaving weaker creditors for the subsidized banking system..$^{15}$ In addition, bank lending may appear to the leadership to be superior to a commercial bond market because bank lending is arguably more easily susceptible to influence by government officials than would be a bond market — both with respect to allocating capital in the first place and with respect to controlling the consequences of a default.

\subsection{The Regulatory Environment: The CSRC}

Prior to 1992, China's infant securities markets had been lightly regulated by local governments and the local branch offices of the People's Bank of China (the PBOC). Following the establishment of the Shanghai and Shenzhen Stock Exchanges in 1990 and 1991, respectively, the State Council,

15. Something rather like this happened in US banking following the great growth in the US commercial paper market starting in the late the 1960s. Strong credits such as General Electric, Ford, GMAC, and other leading firms of the period migrated from bank-revolving credit lines to commercial paper markets to satisfy much of their working capital needs (Johnston 1968; Handal 1972). Indeed, the decline in commercial lending that followed over an extended period would appear to be one of the business drivers for the evolution of the "originate to securitize" model of banking that ultimately played an important role in the financial crisis of 2008 . 
in order to consolidate the complex, multilayered, and fragmented institutional framework for securities trading, in fall of 1992 formed the Securities Committee of the State Counsel (the SCSC) and the CSRC, as the SCSC's executive arm. These new entities were charged to create a centralized supervisory framework for securities issuance and trading in China.

\subsubsection{CSRC's Dual Mandate: Advance State Policy While Also Protecting Investors}

As an executive arm of State Council, the CSRC has a primary obligation to advance state policy and programs. These state aims importantly include successful implementation of the state corporitization program, the development of the securities markets, and the modernization of management of corporatized state-owned firms. In connection with its effort to supervise and guide the development of modern securities markets, the CSRC has adopted approaches that in some respects appear to have been influenced by the structure and policies of the US Securities and Exchange Commission (SEC). In other respects, however, the CSRC's mission and the nature of the PRC governmental structure requires quite different treatment of problems than that of western securities regulators.

As set forth in the PRC (People's Republic of China) Securities Law of 2006, the CSRC's functions are broad indeed. They are to

1. formulate relevant rules and regulations to supervise and administer the securities markets and exercise the power of examination or verification; ${ }^{16}$

2. supervise and administer the issuance, offering, trading, registration, custody, and settlement of securities (including granting or withholding permission to issuers to distribute shares);

3. supervise and administer securities activities of securities issuers, listed companies, securities firms, securities investment funds, securities trading service institutions, stock exchanges, and securities registration and clearing institutions;

4. formulate the standards for securities practice qualification and code of conduct and carry on the supervision and implementation;

5. supervise and examine information disclosure relating to securities issuance, offering, and trading;

6. offer guidance for and supervise activities of securities industries associations;

16. Under the CSRC's direct supervision, the Shanghai Stock Exchange and the Shenzhen Stock Exchange are the major SROs in China. The CSRC holds the power to appoint and remove major officers of the exchanges. The stock exchanges themselves are not empowered with formal investigative and sanction authorities over frauds on the market; the CSRC is. But the CSRC's enforcement capacity is still restrained and the SROs may offer considerable depth and expertise regarding market operations and practices. 
7. investigate and punish violations of any securities laws and administrative rules; and

8. perform any other functions and duties in accordance with law or administrative rules.

The CSRC is widely regarded as one of China's most highly professional regulatory bodies. It has been an active and effective participant in guiding market development, improving market transparency, and in encouraging the development of modern management techniques. ${ }^{17}$ Perhaps its role differs from that of the SEC most fundamentally in that, as an executive arm of the State Council, it has assumed the power to control access to the securities markets by all potential issuers of shares. Thus it acts as a gatekeeper to public finance available both in the initial public offerings and the secondary issuance markets. We turn to this aspect of CSRC functioning first and then to its disclosure policy and enforcement activities. We discuss the CSRC's role in modernization of management later, when we discuss corporate governance of listed firms.

\subsubsection{Access to Listing: The Merits-Based Regulatory Approach}

\section{CSRC as Gatekeeper}

In its role of overseeing the development of the Chinese securities markets, the CSRC seeks to advance state interests by limiting the number of new listing and number of shares to be issued in any period, and by selecting those applicants for initial public offerings or secondary issuances on the PRC securities exchanges. In doing so, it exercises merits-based discretionary judgment. ${ }^{18}$

A number of considerations affect this selection process. In the earliest phase of the process of corporatization and issuance of shares in China, decisions concerning which companies would be permitted to sell listed shares were heavily influenced by local politics. In this period, listing opportunities were allocated among provincial governments on a quota basis. The allocation of this opportunity to local firms was made by local governments, which would be reviewed by the CSRC, who would give final approval. Provincial governments tended to allot these allowances so as to raise money for the SOEs that were the most significant local employers and were most in need of capital. Thus, as it happened, underperforming SOEs were disproportionately selected for listing at the expense of more dynamic entrepreneurial companies (Tan 2006). During this period approximately

17. See CSRC Report (2008) for a comprehensive review of its activities.

18. Article 12, Provisional Administrative Measures of Stock Issuance and Trading (1993); Article 10, the PRC Securities Law of 2006. 
Table 3.5

PORC review results (2004-2007)

\begin{tabular}{ccccc}
\hline Year & $\begin{array}{c}\text { Number of } \\
\text { applications }\end{array}$ & $\begin{array}{c}\text { Number of } \\
\text { approved applications }\end{array}$ & $\begin{array}{c}\text { Number of } \\
\text { rejected applications }\end{array}$ & $\begin{array}{c}\text { Rejection } \\
\text { rate (\%) }\end{array}$ \\
\hline 2007 & 354 & 298 & 55 & 15.5 \\
2006 & 181 & 159 & 22 & 13.8 \\
2005 & 16 & 9 & 6 & 37.5 \\
2004 & 177 & 119 & 58 & 32.8 \\
\hline
\end{tabular}

Source: Shenzhen Stock Exchange (2008).

949 SOEs were listed on the domestic stock exchanges while only 30 private firms were permitted access to the securities markets (Zhang 2002).

This allocation system was modified in 1998 and abandoned in 2001. Currently, in determining whether to permit access to listing the CSRC deploys a process in which a committee-the Public Offering Review Committee (the Committee or the PORC) makes a recommendation respecting access to listing. The PORC is comprised of a minority of CSRC officials and a majority of outside experts in law, accountancy, and financial markets. The decisions of PORC may consider all relevant considerations, including the issuer's qualifications, use of proceeds, legitimacy of business operation, competitive strength, assets' quality, profit generating ability, independence, information disclosure, and corporate governance. ${ }^{19}$ Table 3.5 sets forth the review results of companies seeking to issue shares from 2004 to 2007.

Looking more closely at rejections for the year 2007, one notes that of the fifty-five rejected applications, thirty-eight were for initial public offerings and seventeen were requests for secondary offerings. Among those rejected applications, sixteen were stated as being primarily due to PORC's view of risky or impracticable plans for use of proceeds; fourteen rejections were primarily due to perceived overreliance on business with the controlling shareholders or major clients and the lack of competitiveness or independence; eleven rejections were primarily due to poor accounting practices, such as inconsistent accounting policies, noncompliance in revenue recognition, insufficient provisions and significant contingency issues; eight rejections were primarily due to the failure to meet qualification requirements such as material changes of management in the reporting period; and four rejections were primarily due to insufficient or false information disclosure.

Thus, formally, the CSRC system for allocating listings appears to be moving away from political allocations toward economic merits-based listing

19. The CSRC also has set up a review committee for mergers \& acquisitions and restructuring activities of listed companies in 2008 and a review committee for initial public offering on the Growth Enterprise Board in Shenzhen. 
decisions. There can be little doubt, however, that both political and policybased factors continue to have a large impact on these decisions. First, while geographical allocations to various provinces was formally abandoned in 2001 in favor of an independent merits-based approach, a 2004 study found that the 2003 geographical distribution of IPO fund allocations was not significantly different than the distribution in year 2000 (Chen, Fan, and Wong 2004). Secondly, the number of new listings itself during any period is subject to macro-level policy considerations. Thus, the CSRC may reduce or even eliminate for a time the number of IPOs authorized without regard to the investment quality of any pending applicant for listing. For example, in order to accommodate the nontradable shares reform, all IPO activities were held in abeyance from October 2004 to January 2005 and from July 2005 to May 2006. Also in reaction to the worldwide financial crisis of 2008, in an effort to slow the descent of prices on the Shanghai and Shenzhen Stock Exchanges, all CSRC work on new IPOs quietly came to a halt in mid-September 2008 until late June 2009.

Finally, while recent changes in the IPO listing process clearly appear to represent improvements (if one assumes that the system of access should allow investors access to those firms that have the highest risk adjusted future value) the improved system still leaves substantial room for inefficient allocations both because of human judgment error in being able to distinguish "good" bets from bad ones and from the possibility for corruption that gatekeeper systems inevitably invite.

\section{IPO Pricing}

In addition to access itself, the CSRC has a role in the setting of IPO prices. The CSRC once set bounds on IPO offering prices by a formula in which average firm earnings over the last three years were multiplied by a floor rate (usually 15) and a ceiling rate (usually 20). Within the resulting range underwriters and issuers set an offering price. But unsurprisingly, the setting of such prices, as well as access to the exchange listing itself, has been found to be affected by what might be termed "connections." Based on a study of 423 PRC IPOs during period 1994 to 1999, Francis, Hasan, and Sun (2009) find that, on various measures of political connectedness (e.g., corporate directors who are retired high-level officials), "connected" firms were more likely to receive a higher than median P/E (price-to-earnings) ratio in the price setting process and thus an authority for a higher range of issuance prices.

But not all firms are well connected; for most firms the setting of offering prices tends to be on the low side. This, of course, is true in Western securities markets too. Underwriters want happy investors and even issuers want share prices to rise initially to some extent. Thus it is common to observe average price increases following an IPO. But the degree of underpricing on the Shanghai Stock exchange appears substantially greater than observed 
in the Western markets. Xiu and Chang (2008) found that in China, the degree of IPO underpricing measured by the first-day return is higher than 100 percent, which is larger than almost all the documented IPO initial returns in other countries. See also Tan (2006).

Perhaps responding to this apparent large systematic IPO underpricing, at the close of 2004, the CSRC began to experiment with the introduction of a price inquiry mechanism and book-building process, which would seek to move toward an IPO price more reflective of market sentiment. In accordance with these initiatives, IPO issuers, after receiving CSRC's green light for share issuance, must initially inquire about appropriate IPO prices from at least twenty institutional investors (more if the issuance is planned at 400 million shares or more). Presumably the range of P/E ratios that the CSRC will use setting IPO price ranges in specific cases will take these opinions into account. ${ }^{20}$

\section{Mandatory Information Disclosure}

The quality of information availability is of course a foundational condition for relatively efficient price fixing on securities (or other) markets. Chinese statutory law mandates that issuers accurately disclose all material information and prohibits any material false statement or omission. ${ }^{21}$ Disclosure obligations are periodic and continuous. ${ }^{22}$ To be effective, a disclosure regime requires that the quality of information disclosed is good (truthful, timely and material) and that when it is not that some sanctions be enforced. Despite these legal requirements, however, the credibility of information disclosed by Chinese listed companies is regarded as doubtful by investors and scholars (e.g., Aharony, Lee, and Wong 2000).

There are some efforts to improve the quality of information available. A 2008 study by Shanghai Stock Exchange found that disclosure violations represented approximately 78 percent of all violations punished by CSRC and two stock exchanges for the period of 1996 to 2007 (Shanghai Stock Exchange 2008). An earlier Shenzhen Stock Exchange study covering the period 1993 to 2001 found that material omission and misrepresentation were the two top categories of violations (Shenzhen Stock Exchange 2002). They represented 69.7 percent and 13.3 percent, respectively, of the 218 violations discovered during that period. The absolute number of violations disciplined does not, however, seem large (see section 3.2.3 regarding enforcement).

20. With the introduction of this system, it was found that some institutional investors "conspired" with underwriters during the initial consultation process to drive up initial offering prices, but thereafter withdrawing from the process to allow retail investors to invest at what the CSRC concludes may be artificially high prices. The Chinese regulators are now considering new measures to build up a more reliable IPO pricing process.

21. Article 62, the PRC Securities Law of 2006.

22. Periodic reports include annual reports, interim reports, and quarterly reports. Ad hoc reports are primarily related to material events disclosure. 


\section{Would a Disclosure-Based IPO System \\ Be Feasible for China and Beneficial?}

For the reasons mentioned earlier (i.e., human bias or error in price fixing, the possibility of both political influence and personal corruption), a system of full disclosure and market-based offering prices would no doubt be the policy recommendation of most Western law and finance experts. But it should be acknowledged that a merits-based securities regulatory system may offer benefits in a society in which financial information is not yet of high quality, retail investors' sophistication is not high and market prices appear to be relatively inefficiently set. These conditions appear to obtain in China currently.

Thus, while the CSRC has announced an intention to move toward a disclosure-based system, as Hong Kong, Malaysia, and Singapore are doing, until there is greater respect for the integrity of financial statements, and greater evidence that prices are fixed in an efficient secondary market, ${ }^{23}$ we can expect movement toward a disclosure-based system to be unhurried.

\subsubsection{Enforcement}

It is a commonplace for legal scholars to note the critical role of enforcement in effective securities regulation (e.g., Coffee 2007). The difference between law as written on a page and law as implemented by active agents and courts can be great.

Securities law enforcement is one of the CSRC's major regulatory functions. ${ }^{24}$ Prescribed market misconduct includes: illegal stock offerings, material misrepresentation and omission in connection with the offer or sale of securities, insider trading, market manipulation and professional (securities firm/accounting firm/law firm) misconduct in connection with the offer or sale of securities. ${ }^{25}$ Among the recurring matters that give rise to enforcement activities of the CSRC are disclosure violations and also securities firm misconducts such as misappropriation of client funds and market manipulation. Authorized penalties against public companies or securities firms include disgorgement, fines, ${ }^{26}$ revocations of business licenses, orders

23. We assert that the (relative) efficiency of secondary market prices is a condition for the optimal deployment of a disclosure-based system because the overall character of price setting is what allows the IPO market to estimate value of new issues reasonably well.

24. See Article 180 of PRC Securities Law of 2006. There is some controversy among Chinese academic commentators whether the CSRC as an institutional unit of the State Council (shiye danwei) not an administrative department of the State Council, is authorized under the Constitution to make rather than apply rules. See Clarke (2008), citing Zhou, Zheng, and Hui (1998).

25. See "Interim Provisions on the Management of the Issuing and Trading of Stocks," issued by the State Council, effective April 22, 1993; The PRC Securities Law of 2006, Standing Committee of the National People's Congress, effective January 1, 2006; The Regulation on the Administration of Futures Trading, State Council, effective April 15, 2007.

26. The amount ranges from RMB 100,000 (US\$14,622 equivalent) to RMB 600,000 (US\$87,732 equivalent), 1 to 5 percent of or 1 to 5 times of illegal proceeds. 
of business suspension and internal correction, and warnings or censure. Fines, ${ }^{27}$ an up-to a lifelong bar from the industry, and warnings are available against individuals, including directors and senior management in listed companies.

While it is empowered, it is difficult to say that the CSRC is as an effective enforcement body ${ }^{28}$ For the most part, CSRC's enforcement activities are limited and its penalties are mild. While the number of CSRC enforcement actions has grown as the markets have grown, the number of such actions does not seem large. In the early years, fewer than fifteen cases were investigated and adjudicated annually. In recent years, the number of administrative prosecutions has increased to more than forty. These numbers, however, are small. It is suggestive, but little more than that, given the differences in the scale of US financial markets, but in 2008 for example, it was reported that the SEC brought 671 enforcement actions (SEC 2008). In 2007, the SEC filed 656 enforcement actions (SEC 2007). In 2006, the total had dropped by about 9 percent to 574 enforcement actions compared to the prior year (SEC 2006). ${ }^{29}$ There are grounds to believe that in China powerful SOEs are treated lightly by the CSRC; despite making up a small portion of listed companies in China's securities markets, private companies are more often sanctioned than SOEs. ${ }^{30}$ But it is possible, of course, that the private firms may be less law abiding.

In all events, the result in most CSRC enforcement cases in which a listed company is accused of wrongdoing is censure; fines are quite rare (Firth et al. 2005). Yet Donald Clarke wisely notes that where senior officers of SOEs are state officials, as may be the case in many large SOEs, a censure may be an effective remedy because it is likely to have serious career effects (Clarke 2008).

In recent years private actions by misled investors have been permitted. Enforcement of securities private litigation in the PRC courts is a recent phenomenon. The PRC courts have faced a problem similar to that of the CSRC: they need to provide access to investors claiming fraud often in connection with SOE's issuance of shares, while at the same time considering the interests of state in front of massive private securities litigations. ${ }^{31}$

27. The amount ranges from RMB 30,000 (US\$4,386 equivalent) to RMB 100,000 (US\$14,622 equivalent).

28. It is suggestive that in a study of all voluntary tender offers, Tuan et al. (2007) found that an investor following a long arbitrage strategy on the date of announcement would not profit. The authors infer that information concerning the offers had fully been absorbed into prices before the announcement and that insider trading was the likely technique.

29. In 2005, the SEC filed 629 enforcement actions. See SEC (2005).

30. Liebman and Milhaupt (2008) posit that private firms may be less politically connected than state-owned firms, but they may also tend to have weaker governance.

31. As a supplement to CSRC enforcement, since 2002 CSRC enforcement has been augmented by possible private actions for misrepresentation. See Notice on Accepting Cases Regarding Civil Tort Disputes Arising from Securities Market Misrepresentations, Supreme 


\subsection{Listed Companies: Corporate Governance with Chinese Characteristics}

It is generally thought that one of the institutional preconditions for the evolution of an efficient securities market is the existence of reasonable protections for investors against both the risks of ex post exploitation of their investment and of management incompetence. A potential source of such protections is the system of corporate governance. By "corporate governance" we mean that set of authoritative rules or practices that define how and by whom power over the internal affairs of a business corporation is distributed, exercised, and disciplined. Of course, even countries with successful securities markets differ in the way in which and extent to which this protection is provided. But the Chinese securities markets remind us that what is important is the assurance, not its source. That is, it is not essential that such protections come from a legal system, although the legal system is the formal source of such protection in "rule of law" systems. What is important is that investors perceive in a system a reliable set of practices that offers reasonable protections against ex post investor exploitation or management incompetence.

\subsubsection{Realism and the Governance of Internal Affairs in Chinese Corporations}

Across the world, the topic of corporate governance receives attention from scholars, regulators, and investors. China is not different; both its scholars $^{32}$ and lawmakers (e.g., State Counsel 2004) appear deeply interested in this topic. The CSRC (e.g., CSRC 2003) and the two stock exchanges have addressed the topic of advisable corporate governance structures for listed companies. In this discussion, the very special features of "corporate governance with Chinese characteristics" are not always emphasized. Therefore, we begin our discussion by identifying the most significant aspects of these special characteristics.

Court of People's Republic of China, effective January 15, 2002. In 2003, the Supreme Peoples Court indicated to lower courts that they could accept such actions if but only if the CSRC had imposed a sanction on the party defendant. According to a recent news article, by the end of 2008, approximately 10,000 investors brought suits against more than 20 public companies for claimed damages, totaling about RMB 800 million to 900 million (US\$117.0 million to US\$131.6 million equivalent). Most cases were settled and about 90 percent of the plaintiffs were compensated. See http://finance.ifeng.com/stock/zqyw/20090401/499677.shtml. Additionally, in 2006, for the first time, the PRC Securities Law of 2006 established legal basis regarding civil liability for insider trading cases (Shen 2008).

32. See, for example, Li, Naughton, and Hovey (2008); Allen, Qian, and Qian (2005); and Clarke (2008) for relevant scholarship. 


\section{Government and Party Involvement with Internal Firm Governance}

With its legal system of "corporatized" joint stock companies, shareholder voting, takeover regulation, and derivative lawsuits, China appears formally to be sufficiently similar to European or other western "rule of law" societies to justify discussing its economic control systems in these terms. As we discuss in this part, however, to treat these legal structures as representing the principal supports in the actual system of Chinese corporate governance would be a mistake. Chinese corporate governance is fundamentally different from that in the west. For Chinese listed firms, the formal system of board of directors, share-voting at meetings, of tender offers and of derivative law suits is of little importance in the actual system of power delegation, monitoring or discipline. Rather, actual control over important internal affairs in Chinese listed firms is usually in the hands of a control structures operated by the Chinese Communist Party ("CCP"). That system operates through several avenues. In the largest firms it is operated through a combination of Ministry supervision and CCP Central Committee action. For other listed firms, whether SOEs or "private" firms, that control operates through local, party designated committees that function in each large firm $^{33}$ (Wei Yu 2009), as well as through the operation of local government bureaucracies (Fan and Huang 2010).

The firm-based party committee is an important structure in this regard. This committee, which will be headed by a party secretary who will often sit on the company's supervisory board, will influence the voting of state-controlled shares, will nominate both "independent" directors and insiders, and will have significant influence in designating or dismissing the CEO. As quoted by Howson (2009) from a 2006 interview in Caijing Magazine, Mr. Jiang Chaoliang, the CEO of China Bank of Communications, discussed the role of the party in the operation of the bank as follows:

What does the party committee govern? First, it is in charge of overseeing strategy. The government has a $65 \%$ [share interest in] Bank of Communications, and as the controlling shareholder, it has the power to propose strategic arrangements for the future development of the bank.

33. Concerning party activities, Article 17 of the Company Law of 1993 stated that the activities of the local party committees of the CCP in a firm shall be carried out in accordance with the constitution of the CCP. Article 19 of the 2005 revised Company Law provides that "the organizations of CCP shall be established in companies in accordance with the constitution of the CCP so as to carry out their activities." and it further adds "The companies shall provide party organization with conditions necessary to carry out their activities." Article 31 of the constitution of the CCP assigns the implementation function of higher party decisions to local party committees within firms, while Section 7 assigns the right to supervise party cadres and any other personnel explicitly to local party committees. In effect, this provision gives local party committees a supervisory and monitoring role in shareholding firms (Chang and Wong 2004). 
Second, [the Party Committee] oversees human resources. . . . The Party Committee recommends to the Board of Directors, senior management candidates with the Board of Directors making the final decision. Third, the Party Committee oversees corporate social responsibility such as lawfully paying taxes, operating the business in accordance with law, and not being lawless and chaotic. If the nation implements macroeconomic measures, [the Bank] must abide by these measures [and by implication it is the Party Committee that sees that it does]. (Hu, Cheng, and Fu 2006, 40-41)

Under the Constitution of the Chinese Communist Party (CCP) local party committees are charged to "supervise the members of CCP in the firm" and "implement higher party policy" (Article 31). The Constitution also provides that they "shall not be in charge of business operations of the firm" (Article 32). Nevertheless, as we noted earlier, a member of the party committee usually sits on the board and it is not rare for the party secretary to serve as board chair. Chang and Wong (2004) found that in their large sample, in 16.4 percent of firms the party secretary served also as a senior officer of the company.

In the largest firms, the governance role of the party is formally directed from the central organs of the party. In December 2008, the Organization Department of the Communist Party of China (CPC) Central Committee and SASAC issued a notice that key positions in fifty-three major SOEs must be appointed by the Organization Department of CPC Central Committee. The list of affected SOEs included, among others, ICBC (Industrial and Commercial Bank of China), China Construction Bank, Bank of China, China Life Insurance Co., China National Overseas Oil Company, China Telecom, China Oil \& Foodstuff Co., and China Coal Co., Ltd. Key position generally include Chairman of Party Committee, Chairman of Board of Directors, and President or CEO of SOEs. In smaller enterprises the province-level CCP designates local party committees.

Thus, while the process by which senior officers are designated, paid, and promoted or disciplined is formally a corporate process, in reality it is dominated by party processes. Presumably the designation of officers is based on a blend of considerations, including both competence in administration and on political reliability or connections. Relations between party committees in legal person shareholders and those in listed firms is an internal party matter that occurs behind a veil. Sometimes, apparently, the party committee of a parent company may not appoint a committee in the subsidiary, but itself function directly in that capacity (Wei Yu 2009).

In fact, as the quotation of Jiang Chaoliang suggests, in China's listed SOE firms the formal board of directors has tended to play a secondary and formal role, with the party committee directing matters (through the board or otherwise) that it deems important. It is reported that the party exercises its influence primarily on questions of strategy and personnel, 
going much deeper into the organization than simply designating the CEO (Wong, Opper, and Hu 2004). While they exercise great influence or control over corporate processes, party committees owe no fiduciary duties to public shareholders. Each party committee fits into the CCP governance structure that establishes appointment, goal setting, reporting, and disciplinary structures (Howson 2009; Wei Yu 2009; and Pistor 2013).

Finally, with respect to smaller listed firms, the multidimensional involvement of local bureaucracies, which has been studied by Fan, Wong, and Zhang (2007) and Gordon and $\mathrm{Li}$ (2013), radically reduces the scope of areas over which even effective instruments of shareholder-centered corporate governance could operate.

\section{Does the State (Party) Governance Role Help or Hurt Public Shareholders?}

The conventional scholarly view of this degree of political control of the internal affairs of a business corporation is that it will tend to be inefficient, diverting corporate resources away from activities designed to maximize market returns toward the achievement of political objectives, including unnecessary employment (e.g., Blanchard and Aghion 1996; Hellman and Schankerman 2000). The policy implication of this view is unambiguous: reductions in political control should be associated with more efficient firms. Some studies find this effect in China for SOEs (presence of party secretary associated with poorer operating performance and lower labor productivity) (Wei Yu 2009).

Other scholars, however, deploying the same theoretical framework, have seen the question of CCP's role in the corporate governance of Chinese listed firms in a more subtle way. They point out that while party committees certainly may involve the potential inefficiency of diversion of resources, or of excessive local employment, these committees may also have other positive effects from the point of view of the firm. They may assist management in securing limited resources (such as land, finance, or possibly IPO allocations) and may limit both managerial agency costs and controlling shareholder expropriation (Che and Qian 1996). Moreover, the incentives of bureaucratic actors in China are to some extent aligned with long-term investors' interests, in that it is understood that a key metric in bureaucratic promotion is growth in GDP in the province or region. On this more textured view, the systemic effects of party committees or of local government actors on the efficiency of listed firms presents a difficult empirical question. The studies done - based largely on accounting measures - are inconclusive; they suggest that for their sample as a whole party committees add value in constraining agency costs of management but are associated with inefficient levels of employment (Chang and Wang 2004).

Alongside its system of direct and indirect Communist Party control, China has developed the legal infrastructure of liberal corporate governance. We turn now to a discussion of this formal system. We suggest that 
the legal system represents a supplemental system that has two main purposes: it offers some assurance to foreign investors and may help in the modernization of management of listed SOEs. In the following sections of this part, we discuss the current status of formal governance system. In section 3.3.2 we discuss the command and control type of governance that originates chiefly in the CSRC. In section 3.3.3 we discuss formal legal governance rights of investors, which will look familiar to those familiar with Western corporate governance mechanisms.

\subsubsection{Top-Down Corporate Governance in China: The CSRC Governance Role}

In addition to other aspects of $\mathrm{CCP}$ direct and indirect corporate governance power, the CSRC exercises significant authority with respect to the establishment of certain governance standards and practices for listed firms.

\section{The Code of Corporate Governance for Listed Companies}

In 2001, the CSRC issued its Code of Corporate Governance for Listed Companies. ${ }^{34}$ In this code the CSRC, in ninety-five numbered paragraphs, establishes standards for corporate governance. They include three paragraphs on Related Party Transactions (12-14), seven paragraphs on Behavior Rules for Controlling Shareholders (15-21), six paragraphs (22-27) on the Independence of the Listed Company, and three paragraphs on Disclosure of Controlling Shareholder's Interests (92-94). These rules of corporate governance plausibly seem directed toward protecting holders of state (formerly) NTS (and public shareholder incidentally) by forcing disclosure by legal person shareholders.

In addition, the CSRC establishes rules for board procedure (44-48), for specialized committees of the board (52-58), and for Performance Assessments and Incentive and Disciplinary Systems (69-72). These rules seem directed to instructing management (and controlling shareholders of legal person shares) about best management practices.

In fact, agencies of the state with large economic interests in residual earnings of listed SOEs would not be dependent on regulatory or judicial remedies in responding to mismanagement self-dealing or even for poor corporate governance practices. If SASAC, as the body holding the residential state interest in many publicly listed SOEs (or the Ministry of Finance in the case of the largest banks) or other agencies, learn of mismanagement, they can and presumably are expected to act through government or Communist Party channels for redress or discipline. Thus, a plausible explanation of the

34. English translation of this Code is available from http://www.csrc.gov.cn/n575458 /n4001948/n4002030/4062964.html. 
2001 CSRC Corporate Governance standards is that in it, the CSRC in effect provides such state agencies with expert guidance or standards respecting the topics it covers. Simultaneously, these standards and practices may serve to induce listed SOEs (and other listed firms coincidentally) to adopt more transparent and modern management and governance practices.

\section{Goals of CSRC's Formal Governance Activities}

More fully, we suggest that in promulgating the Corporate Governance Code or other governance-type regulations the CSRC seeks to advance three main aims. First, the promulgation of sensible governance standards and practices will offer some assurance to foreign institutional investors on the Hong Kong or New York exchanges that investment in the large PRC SOEs listed on those exchanges constitutes an investment in a sensibly governed, modern commercial enterprise. Currently, as we indicated previously, Hong Kong appears to be more important for raising capital for such firms than Shanghai and those shares enjoy special class voting rights.

The second reason we suppose that CSRC engages in serious corporate governance activity, even though public shareholders have virtually no ability to enforce such standards (as we see later), involves the apparent aim of the leadership to construct the infrastructure for a modern securities market - including statutory shareholder rights, fiduciary obligations, and the modern standards of corporate governance - as an option for future finance of SOEs. The Share Segmentation Reform was an elaborate, timeconsuming effort to make it possible to sell to public investors more of the state's share interest in large, listed SOEs. That effort must have been motivated by a desire to sell more stock to Chinese and (to some extent) overseas institutional investors. Time will tell to what extent these sales will occur and with respect to which firms. But, as with foreign investors in Hong Kong (as well as other overseas markets), it is reasonable to expect that Chinese investors, especially institutional investors, will at that time be more likely to make further investments in SOEs at not-excessively discounted prices, if those firms appear to be governed by structures and "rights" consistent with those pertaining in other markets.

The third, and we suggest the most important, reason that it makes sense for the leadership to authorize the CSRC to promulgate (and care about) corporate governance practices, even though shareholders have virtually no way to enforce such standards, is that these standards may also be thought of as attempts to modernize management practices of SOEs and to coordinate $\mathrm{CCP}$ governance of firms. Modernization of management of its state sector is important to China and the modern SOEs constitute a vital part of that sector. Listing standards on the exchanges and regulatory requirements by the CSRC can be seen both as a way to control undesirable management practices (such as self-dealing transactions) that hurt the state as a share- 
holder (and incidentally hurt public shareholders) and as a way to encourage the development of better management techniques, such as better financial reporting or incentive compensation programs. ${ }^{35}$ The CSRC as a specialist organization will obviously be more knowledgeable than decentralized party committees in establishing such things as transparent accounting standards or responsible management practices, in which the state and the party have an interest.

\subsubsection{The Limited Role of "Internal" Corporate Governance in Chinese Securities Markets}

We turn now to the formal legal system of investors' rights that appear in many respects similar to shareholders' rights in the United States or other Western systems. We structure this discussion of the formal aspects of Chinese corporate governance around three primary investor governance mechanisms: the investors' rights to vote and to sell shares, thus facilitating a change in control and to sue.

\section{Public Shareholders' Right to Vote}

Turning first to the right to vote, we note that while all shares listed on Chinese securities exchanges carry one vote, voting rights with respect to PRC listed firms must be understood in the shadow of the fact that, in essentially all cases, block holders hold controlling blocks of shares. In SOEs, the controller is typically state affiliated; in the 20 percent or so of listed firms that are not SOEs, the controller is an individual, family, or affiliated groups of investors. Thus, at first glance one would conclude that for public investors, corporate voting is almost wholly immaterial. This, while largely true, may not be entirely so.

Since one aim of the corporitization and listing process has been the attraction of capital - and as we show earlier, predominately foreign capital - to listed firms, it was seen as prudent, if not essential, to offer certain limited protections to foreign investors against the risk that a simple majority vote of shares could alter the character of their investment once it was made. This protection was offered through a mandatory class voting right for H shares (and other overseas' listing shares, if any) for the approval of transactions or charter amendments that would constitute an abrogation or variation in the rights of the $\mathrm{H}$ shares (or other overseas' listed shares, if any). ${ }^{36}$ The mandatory provisions identify the various types of corporate actions (identified in footnote below) that require a class vote of $\mathrm{H}$ shares

35. See CSRC, Guidelines for Equity-based Compensation (2005, No. 151) (restricted stock and options as compensation limited to 10 percent of outstanding shares).

36. Mandatory Provisions for Articles of Association of Companies to Be Listed Overseas were issued in 1994 jointly by the Securities Commission of the State Council (then the parent organization to the CSRC) and the State Economic System Restructuring Commission. 
(or other overseas' listed shares, if any) to be implemented. ${ }^{37}$ The voting rule to determine such class votes is set at two-thirds of the issued and outstanding H shares (or other overseas' listed shares, if any). The class vote right can offer substantial protection to foreign investors in covered matters.

There exists another share voting protection of some significance that relates to related party transactions. Under "Guidelines for Articles of Association of Listed Companies" first issued by the CSRC in 1997 and revised in 2006, the authorization of any related party transactions that requires a shareholder vote requires that only disinterested shareholders vote. In practice, listed companies have adopted this provision in their articles of association. Not all related party transactions do require a shareholder vote, however. According to the Listing Rules of the Shanghai Stock Exchange, a shareholder's vote is required in three cases: if the transaction is approved by fewer than three "independent" directors or the transaction is large (greater than 5 percent of net assets and in excess of RMB 30 million) or there is a guarantee issued by the company to a related party.

Shareholder voting might in the future become more important in Chinese corporate governance, now that share segmentation reform is largely completed. But it remains to be seen whether and when some firms will in fact distribute their formerly nontradable shares to the public and how many shares will be distributed in this way. Certainly these holders will have a substantial economic incentive to sell at market prices if, as has been the case in the past, the market prices are higher than the private market prices.

If and when control of some listed firms does become available in the securities markets, a number of very important corporate governance issues will be faced. Some of these are mentioned in the following in connection

37. Art. 80 of chapter 9 of the Mandatory Provisions provides the following situations that shall be considered as a variation or abrogation of the rights of a certain class of shareholders: (1) the increase or reduction of the number of shares of that class of shares or the increase or reduction of the number of shares in another class which carry the same or more right to vote, right of distribution, or other privileges; (2) the conversion of all or part of the shares of that class to another class, or the conversion of all or part of the shares of another class into the shares of that class or the granting of such right of conversion; (3) the cancellation or reduction of the rights of that class of shares to receive dividends declared or accrued; (4) the reduction or cancellation of the preferential rights of that class of shares to receive dividends or to receive distribution of assets upon the liquidation of the Company; (5) the increase, cancellation, or reduction of the share conversion rights, options rights, voting rights, rights of transfer, preemptive rights, and rights to acquire the securities of the Company of that class of shares; (6) the cancellation or reduction of the rights of that class of shares to receive payment payable by the Company in a particular currency; (7) to create a new class of shares that enjoys the same or more voting rights, distribution rights, or other privileges than those enjoyed by that class of shares; (8) to restrict or increase the restriction on the transfer or ownership of that class of shares; (9) the granting of subscription rights or conversion rights in respect of that class or another class of shares; (10) the increase of the rights and privileges of another class of shares; (11) the reorganization of the Company as a result of which different classes of shareholders assume obligations otherwise than in proportion; and (12) the amendment or abrogation of the provisions in this chapter 9 . 
with tender offers for control, but others will relate directly to shareholder voting. Given the high cost of any shareholder-initiated proxy contest, the most significant of these issues will be whether and on what terms shareholders might have access to the company's proxy statement, which has been a contentious issue in the United States for some time, and whether successful proxy contestants can get reimbursement for some or all of the costs of the contest and under what circumstances.

\section{Public Shareholders' Inability to Participate in Disciplinary Tender Offers}

In systems in which control over listed companies is in the market ("Contestable Control Systems"), the mechanism of hostile changes in corporate control has been treated both by scholars of law and of finance, as well as governance activists as the ultimate market corrective for inefficiency of management (Easterbrook and Fischel 1991; Bebchuk 1987). The theory is well-known. The evolution of a disciplinary "market for corporate control" is often seen as a potentiality that can be useful in systems in which securities markets play a major financing role. But as neat as the theory of a market for corporate control appears to be, there are substantial grounds to believe that the types of costs and imperfections that affect the efficiency of securities markets generally (e.g., principally information problems, agent's incentive misalignment problems, and systematic limitations of human rationality) coupled with recurring periodic excess system liquidity, render this market far from perfect (e.g., Schleifer and Summers 1988; Lipton 1997). Thus, in the United States there has long been a debate concerning how "free" the market for corporate control should be. There are, of course, numerous techniques open to any legal system for moderating the market for corporate control when it is permitted to exist: approval of "takeovers" by substantive regulatory agencies where there is a strong public interest in the industry; ${ }^{38}$ enactment of "constituency" statutes or regulations that give nonshareholder constituencies a legally cognizable interest in such transactions (Allen, Kraakman, and Subramanian 2012); authorization of "poison pill" securities which give boards of directors certain powers to defend against unwanted takeovers (Kahan and Rock 2002); and less powerful company law devices, such as staggered election of the board of directors (Bebchuk, Coates, and Subramanian 2002; Bebchuk and Cohen 2005). China need not address these secondary issues relating to a market in corporate control at this time because, while tender offers for control are legally possible, in fact there is virtually no market for corporate control. ${ }^{39}$ "Takeovers" play no disciplinary role in China today.

38. Thus most systems require governmental preapproval of changes in corporate control of major financial institutions.

39. In an apparent effort to aid public shareholders, the CSRC issued "Measures for the Administration of the Takeovers of Listed Companies" in 2002 and revised in 2006, which for the first time contemplated public tender offers for shares of listed companies in China. 
Some "change in control" transactions do occasionally occur in China, but they are in the form of contracts in which an acquirer contracts with the holders of some or all formerly nontradable shares for transfer of controlling block of stock. The state - that is both CSRC and often SASACmust consent to such a transfer of control where state-controlled shares are involved. When these transfers involve listed companies, under CSRC regulations, the buyer is required to extend a tender offer to all public shares at a price no less than that paid in the control transfer ${ }^{40}$ (Such a rule is called a mandatory bid rule and is common in the European Union and under some state law systems in the United States.) While the beneficial effect of mandatory bid rules is controversial (Easterbrook and Fischel 1989), what is notable is that in China such tender offers, when they occur, are merely formal and have no economic effect at all.

Professors Tuan, Zhang, Hsu and Zhang located just twenty-four instances of tender offers for shares of listed firms in China between June 2003 and December 2006 (Tuan et al. 2007). Of these, seventeen tender offers were "mandatory" in character and offered a price below the market price for the traded A shares! That is, in these cases, the price per share paid for the control block was below market price for the traded shares! Thus the public tender offer required by the CSRC mandatory bid rule could be and was made at a below-market price. The authors report that on average the discount from market price offered was 19.6 percent. Unsurprisingly, none of these offers closed. We might call these tender offers "phantom tender offers," because they have the formal look of a tender offer, but have no economic substance. The remaining seven cases of tender offers were cash tender offers. All of these bids were in the petroleum and chemicals sector and all were initiated either by Petro China or by Sinopec, the giant SOEs in the petroleum business.

More interesting than the question of why do buyers of control offer a price below market - having acquired control, they apparently saw no advantage in buying out the public shares - is the question, why do the original holders of control agree to sell at substantial discount to market price? A standard answer, grounded in a belief in the fundamental efficiency of stock markets, would be that very large blocks often trade at a discount due to market illiquidity. An alternative possible account of this phenomena would posit that the market price for noncontrolling A shares is recognized by both buyers and sellers of control to be irrationally high on the Shanghai or Shenzhen Stock Exchanges, at least part of the time. That is, there may at times be a bubble premium reflected in the market that more informed and rational buyers are unwilling to pay.

40. More specifically, whenever a holder acquires 30 percent or more of the traded shares of a listed company, the mandatory bid rules require a tender offer to the public shareholders at a price no less than a price set by a multifactor test (Huang 2008). See Article 24 of Measures of Administration of Takeovers of Listed Companies. 
In all events, we observe that, even though the legal technology to govern tender offers has been well developed by the CSRC (Huang 2008), at least for the present, tender offers for corporate control play little role in Chinese corporate governance. The CSRC's formal takeover regulation appears to be another example of the development of a future option available to the leadership. Whether disciplinary takeovers in fact will be observed in the future in China will depend on two factors. First, will control of (some) listed firms actually become available on the market (i.e., will state-affiliated holders sell control of SOEs into the market?) and second, should this occur, will the leadership permit the management of listed firms to be determined by a market for corporate control processes? That, of course, appears to be unlikely now or in the intermediate future. The more likely role for takeover regulation is to offer some modest protection to minority shareholders as control blocks are in the future shifted as part of industry consolidations or other restructurings. Moreover, given the likely inefficiency of the pricing of shares on the mainland exchanges, even if shareholdings were such as to make hostile takeovers feasible, there is doubt that they would serve useful public purpose at this time.

\subsubsection{Chinese Courts and Shareholders' Right to Sue}

\section{The Institutional Contributions That Courts Can Provide}

While administrative agencies such as CSRC can act as powerful instruments in structuring and operating a system of market regulation, courts could supplement such activity in useful ways. Courts can give force and effect to abstract statements of law by determining contested facts and declaring and enforcing rights and duties of managers, shareholders, or directors in those factual contexts. Among the institutional advantages of courts are the following: (a) well-functioning courts offer a professional commitment to make decisions only in accordance with preexisting law and to be unaffected by other matters; (b) they have expertise in the content of preexisting law and in accepted professional techniques of interpretation of it; (c) they make decisions grounded in the facts of a particular case, which are determined in an unbiased manner; and (d) they often or usually provide written justification for their results. In a judicial system in which courts function in this way, citizens know after a litigation has been determined that they have been heard by a disinterested judge with expertise who has ruled according to law. In this way, well-functioning courts can provide a form of satisfaction even to parties who lose their disputes. The reliable provision of these services can ex ante facilitate investment and, more broadly, contracting among strangers.

As an arbiter of disputes between shareholders and those controlling the management of the firm, courts could serve a corporate governance function 
either at the instance of government actors (e.g., administrative agencies) or at the instance of shareholders directly. In fact, since the 2006 amendment of the Company Law, Chinese courts have been authorized to adjudicate claims of director wrongdoing in so-called "derivative" lawsuits- that is, a suit brought by a shareholder in the name and for the benefit of the corporation itself. ${ }^{41}$ Such suits are brought against the corporate directors or officers who are alleged to have violated their duty and injured the company in some way.

Derivative lawsuits can be subject to abuse, but they can serve as an important constraint on corrupt behavior. Generally, these suits can be useful even if directors are not frequently required to pay damages for wrongs in such lawsuits. In the United States, most such suits are settled through the payment of a relatively small payment from an insurance underwriter. Nevertheless, such suits are useful to investors because, ex ante, directors adjust their behavior knowing that in certain types of transactions they face a high probability that their conduct will be subject to derivative litigation and thus close judicial review. Thus the existence of this type of lawsuit and the legal infrastructure that permits them to be brought, can serve an important chilling effect on violations of the corporate directors' fiduciary duties.

\section{"Fiduciary Duties" and Shareholder Suits in China}

Formally, the corporate board of directors, under Chinese company law and that of most Western countries, holds power over corporate managers; it is responsible for overseeing the operation of the company. If those individuals wrongfully injure the corporation, under most systems they can be held responsible and in some jurisdictions, including China, they may be held liable for such harm in a suit brought by shareholders on behalf of the corporation itself. Most such suits would charge a violation of a general duty to try in good faith to undertake transactions only in an effort to advance corporate purposes. Such a duty is generally characterized as the fiduciary duty of loyalty. As part of the early corporatization movement, the first modern PRC Company Law of 1994 did expressly state that officers and directors of companies formed under its authority ${ }^{42}$ shall be liable for damage caused to the company by their violation of law, administrative regulation, or the company's articles of association. ${ }^{43}$ It did not mention any concept similar to the open-ended fiduciary duty of loyalty and, more importantly, did not authorize shareholders to initiate any action upon an

41. For a full description of derivative suit, see Allen, Kraakman, and Subramanian (2012, chapter 10).

42. For example, Articles 59, 60, and 61, the PRC Company Law of 1994.

43. See Article 63, the PRC Company Law of 1994. 
allegation of such unauthorized conduct nor was it interpreted by courts to do so.

Nevertheless, some PRC courts did from time to time signal receptivity to the idea of a shareholder suing on the corporation's behalf to redress injury caused by an alleged violation of law. ${ }^{44}$ In 1997, a court in Fuijian Province upheld the right of a minority shareholder (in a joint venture corporation) to sue on the corporation's behalf on a debt where the majority of the board were related to the debtor, and had refused to do so. The courts said:

If the infringement suffered by the shareholders is to the right of the company, then the shareholders should first present a written application to the organ of power of the company requesting that the company take action. ... Where the company does not take any action, the shareholder may in its stead bring a lawsuit." (Clarke 2008, citing Xie and Chen 2001)

This is a clear statement of the derivative theory, and its articulation by a Chinese provincial court in 1997 evidences the strong appeal of the logic of the form of action. Nevertheless, other provincial courts during this period rejected the theory (Shen 2008; Deng 2005). ${ }^{45}$

In its Corporate Governance Code, the CSRC endorsed the concept of the derivative lawsuit when, it stated that:

Shareholders shall have the right to protect their interests and rights through civil litigation or other legal means in accordance with law and administrative regulations. In the event the resolutions of the shareholders' meeting or the resolutions of the board of directors are in breach of laws or administrative regulations, or infringe shareholders' legal interests or rights, the shareholders shall have the right to initiate litigation. (CSRC 2003)

But it is not free from doubt that the CSRC intended to try to advance derivative lawsuits by this provision. This translation of the language of Article 4 of the Corporate Governance Code appears on the CSRC website. Some scholars, however, translate the provisions as giving shareholders only the right to demand the company initiate lawsuits (Clarke 2008).

\section{Derivative Suits and Shareholder Problems of Collective Action}

Despite the shadowy legitimacy of shareholder derivative suits prior to the 2005 revision of the Company Law, the legitimacy of the shareholders'

44. An early example, dealing with a foreign joint venture involving the Zhangjiagang Fiber Company in which the Supreme People's Court allowed a Chinese joint venture partner to sue on behalf of the joint venture when the managing partner had refused to do so, allegedly because it had inappropriate motivations. See Deng (2005).

45. San Jiu Pharmaceutical Company, where the Shenzhen Basic Level People's Court rejected a derivative suit unless unanimous shareholder action was taken (an obviously impossible precondition to such suits). See Deng (2005). 
derivative suits in China was made clear in Article 152 of the PRC Company Law of 2005. That enactment specifically acknowledged corporate directors owe fiduciary duties of loyalty and care (Art. 146) and also authorized derivative suits by shareholders. The preconditions to such suits are as follows: first, plaintiffs must represent more than 1 percent of the shares of the company for more than 180 consecutive days, alone or jointly. Second, demand to sue must be made upon the board of directors and suit may be filed only after thirty days following such a demand. The latter prerequisite is designed to allow the corporate board an opportunity to study the matter and take action with respect to it. It is a conventional precondition to such suits in the United States. The first requirement appears to be an attempt to limit so-called "strike suits" brought by persons with insignificant equity investment merely for the purpose of extracting a nuisance settlement. It may, however, serve as an impediment to meritorious claims also.

It is early to judge whether this new statutory authorization may in time provide a remedy that is useful to shareholders, but there is, in the short term, little hope for a strong investor protection tool at present, with respect to listed companies. The problem stems from the fact that investors who buy shares on securities markets generally face severe collective action disabilities caused by their small proportionate interest in the firm. There appears to be little willingness to innovate a solution to the collective action problem that potential shareholder plaintiffs would face. For the holder of a relatively small proportion of total shares, the costs of suit would be prohibitive, even if the claim to be litigated seemed quite strong, unless there were a mechanism to allow these costs to be shared among all other shares. Yet neither the statutory law nor judicial innovation recognizes a way to impose this cost sharing.

Thus, the few derivative cases that are found in modern Chinese law tend to be cases involving joint ventures in a corporate form. In those cases, the representative plaintiff necessarily owns a large proportionate share of the firm (and potential damages). This may provide sufficient economic incentive for him to bear the costs of bringing such a suit. Where the investor's stake is proportionately small, however, unless there is a way to force the sharing of his costs, such an investor will not sue, even if the violation is clear. But neither the PRC Company Law, nor the few courts who have discussed derivative suits, have suggested that costs of this litigation, including attorney's fees, might be awarded to a successful derivative plaintiff. Therefore, it is not to be expected that shareholders who acquire shares on the exchange will undertake to fund such litigation, where they own only a minor percentage of the company's securities.

Thus despite the fact that formally Chinese law has adopted the investorinitiated derivative suit, at this time courts are not in fact a realistic source of constraint on management misbehavior in Chinese listed companies. 


\subsection{The Future of China's "Top-Down” Securities Markets}

\subsubsection{Assessing Chinese Security Market Growth}

The creation in less than twenty years of the complex technological, financial, and legal infrastructure necessary to operate the two mainland securities exchanges is unquestionably a great achievement. With these exchanges, and the corporatization effort that is their premise, the people of China have created one of the essential working parts of a world-class economy. They have successfully organized the former state and provincial production facilities into individual firms in which professional managers can direct activities with an eye to market-oriented production. They have created embryonic corporate governance structures and a structure of legal rights and duties that might be used to create more highly elaborated investorbased corporate governance protections in the future. They have created a means for the corporatized firms to access domestic household savings and world global investment pools. They have created the option to institute some forms of stock or stock price related incentive compensation for professional senior managers. And they have made initiating some forms of capital markets-based disciplinary methods (such as takeovers) a policy option for the future, as well.

Nevertheless, in their present state these markets represent more potential value to China than realized value. They are not economically highly important yet. While the equity markets have grown rapidly in terms of market capitalization and in terms of listings, when compared to the securities markets in more developed financial systems, they appear as quite small relative to the Chinese economy. They lack deep liquidity and are excessively volatile; there is good evidence that they do not price equities very efficiently. An economically significant market for nongovernmental bonds has not yet arisen in China and is important. Financial risk management has been severely limited, in part because hedging opportunities are constricted by a prohibition, now to be eased, on borrowing shares. Futures markets for securities are in their infancy. Quite significantly, the public markets continue to offer little assistance in funding growth in the important nongovernmental sector of the economy. And by most accounts there is significant level of managerial and other forms of corruption and virtually little investor corporate governance remedies available.

\subsubsection{Future Development Steps}

A more important role for securities markets could include, most importantly: (a) broader access to the securities markets for the purpose of raising capital for the entrepreneurial sector of the economy; (b) the development of a substantial commercial bond market open to all corporate borrowers of 
requisite credit standing; (c) the development of an array of financial instruments capable of hedging of financial risk, which is now beginning; (d) the gradual floatation into the market of a majority of outstanding voting stock in a significant number of former SOEs; and possibly, (e) the development of public shareholder protective institutions of corporate governance, as discussed before, including development of the infrastructure necessary for proxy voting, tender offers and shareholder law suits. Consistent with policy on the country's currency, a more developed PRC securities market might also involve: (f) easier access for foreign investors to Chinese markets and securities; and (g) easier access for domestic investors to foreign shares through the Hong Kong or Shanghai Stock Exchanges. Were the leadership to permit and direct this further development of the securities markets, we would expect those markets to more effectively provide to the Chinese economy the three great benefits of fully developed securities markets: (relatively) efficient capital allocation, flexible financial risk management, and useful techniques of financial market discipline of ineffective corporate management.

Expansion of the use of securities markets would have distinct economic or development advantages for China, but it would raise two related issues. First, more significant securities markets would heighten political issues of Communist Party control that economic liberalization generally and securities markets particularly have raised from the beginning of reform. A market allocation of capital and market discipline of managers, if they are to be effective, would entail reduction in the ability of Communist Party committees to direct economic development, to appoint senior managers of firms, and to direct operational outcomes on the firm level. While in the event of such liberalization, the sovereign power of the government could redirect its control to external tax and regulation of business to some extent, such a system would inevitably have less direct and immediate control over listed firms than the present system offers. Thus, these are effects that are unlikely to be eagerly embraced in the near future. Secondly, and more abstractly, fundamental growth in the securities markets (meaning a change in their structural limitations) raises the question: To what extent does or should China wish to expose its economy to the types of gyrations which the financial crisis of 2008 and 2009 has shown, again, that capital markets including securities markets are capable? The claim of some in the United States that its system, dominated by financial markets of ever greater complexity and shorter average holding periods, has become unduly short-term oriented, is often dismissed by academic commentators. But it is unlikely that the near collapse of the US financial system in the fall of 2008 leaves its model of finance in quite the same position as a role model. China's quick bounce-back from the global financial crisis of 2008 and 2009, on the other hand, leaves its leadership or elements among its lead- 
ership in a position to question the value of such capital market liberalization.

Almost certainly the leadership will feel its way in assessing the risks and benefits of further expansion of the economic role that securities markets play in the Chinese economy. We do, however, have least two telling bits of evidence of an intention to foster further development of the Chinese securities markets. First, despite its occurring before the global financial crisis, the elaborate effort of the Chinese government to remove the NTS designation (briefly outlined in this chapter) provides strong evidence that the leadership recently intended for the securities markets to have the capacity to grow into more powerful instrumentalities of finance. Second, more recently, the 2010 approval of futures trading and short selling innovations confirm that intent is unchanged.

Of course, it is very unlikely that the leadership will, for the foreseeable future, allow the most significant components of the economy-the large banks and insurance companies, natural resource companies, the national transport infrastructure and the telecom industries, for example - to be subject to the risk of investor "interference" that might potentially occur if a majority of voting shares of these firms were traded in the markets. But, we assume, that in the next period of development (whenever that may occur) the leadership will direct that a majority of the shares of at least some SOEs in nonstrategic sectors of the Chinese economy be moved from government control into nongovernment, including market control. Thus, we expect certain firms in consumer electronics and soft goods, textiles, footwear, recreation and leisure, home supplies and repair materials, health, beauty, and hygiene products, and various other nonstrategic products or activities to increase the proportion of their shares that trade on securities markets. Furthermore, we expect that CSRC continuing current efforts to open the securities market to smaller entrepreneurial enterprises will meet with some success and we will in the future observe greater use of securities markets by private entrepreneurial or foreign firms. Even these steps, however, will take time.

\subsubsection{The Secondary Role of Legal Infrastructure in Chinese Securities Markets}

Continued growth in Chinese securities markets, however, is not dependent on improvements in the legal infrastructure of those markets. While the attractiveness of those markets to investors would be increased by, for example, the improvement in quality of financial disclosure, the reduction in insider trading, or improvements in corporate governance generally, such changes are not essential presently. Chinese securities markets will continue to attract domestic and international investors without improvement in corporate governance protections for the immediate and indefinite future. 
Even substantial levels of investor exploitation by managers or by controlling shareholders-for example, insider trading, self-dealing transactions, or other forms of corruption - need not prevent the development of a large or growing securities market.

What is essential for these markets to continue to grow is only that the perceived expected risk-adjusted returns available to investors, net of the expected cost of exploitation, is attractive when compared to all alternative opportunities to invest funds. Therefore, so long as the net returns expected to be generated on Chinese securities markets exceed risk-adjusted expected returns offered by alternative investment opportunities, Chinese securities markets will continue to attract investors. It is the growth of the Chinese economy, not the improvement of Chinese corporate governance, that is the primary driver of the growth in the Chinese securities markets. While there has been some controversy about just how accurate the reported growth rates for China have been, there is no doubt that real growth rates over the period 1990 to 2008 have been very high. ${ }^{46}$ Indeed, some informed views see this growth rate continuing for a substantial period (Fogel 2006).

\subsubsection{Are Investor-Initiated Protections and More Efficient Securities Markets Likely in Modern China?}

The fact that we can expect the Chinese securities markets to continue to be highly attractive to international investors, even if we expect no improvement in legal infrastructure of those markets, does not mean improvement in corporate governance and other public investor protections is unimportant for China. The logic is compelling that, holding all other factors constant, an improvement in the range of financial products available in the securities markets, in access to listing and in the quality of disclosure together with a reduction in the amount of investor exploitation, would reduce the costs at which capital would be committed to investment in China and improve the efficiency with which capital would be allocated among potential users. Regardless of the period in which elevated growth rates can continue, experience teaches that, in time, these growth rates will reduce. When that occurs, the marginal improvement in costs of capital that investor protective governance can yield systemically will become relatively more important.

As one looks to that future, one can imagine the leadership of the country considering steps to try to make investment in China more attractive both

46. While officially reported statistics on Chinese GDP growth rates have been controversial, see Thurow, Zhou, and Wang (2003) (using data on electricity consumption to cast doubt on reliable of official GDP growth rate numbers). Official government sources reported the average real growth of GDP over the period 1999 to the close of 2008 was 14.4 percent per year. See China Statistical Yearbook (2008). 
to international capital and, more importantly, to domestic savers. Obvious first steps would be improvements in transparency, in reducing corruption and management inefficiency. The first instinct will presumably be China's traditional top-down style response - that is, an increase in CCP campaigns to encourage right conduct and diligence. Should such campaigns fail, as one might expect, then we would expect the second top-down response: greater or more effective party discipline or official prosecution of corruption. But there are reasons to think even that technique would, alone, be ineffective. Public officials or party secretaries are likely to have either poorer quality information concerning breaches of fiduciary duty (or subpar managerial performance) or weaker incentives to take corrective action than investors, whose financial interests are adversely affected by managerial conduct. Therefore, at some point in time the leadership of the country will experience increased pressure to improve the whole range of practices concerning internal corporate affairs. When this does occur the leadership will face again some recurring issues: how much can decentralized, shareholder-initiated mechanisms be trusted; how much can "rule of law" institutions, such as shareholder voice and independent courts or free access to listing by all who meet objective criteria, be made consistent with China's culture and existing political institutions?

Can fostering better disclosure, less administratively controlled access to finance, and greater privately-initiated governance mechanisms be consistent with the leadership role of the CCP in China's one-party state? There seems to be no reason in logic why it cannot. Control over law creation, taxation, and law enforcement (not to mention appointment and pay of the judiciary) provides sufficient levers to allow the leadership effectively to guide the direction and speed of economic growth without losing that degree of control necessary to safeguard those values that the leadership holds most sacred. Yet change always does entail unforeseen risks. Much of the magnificent success that has occurred in the development of the Chinese economy over the last thirty years, despite being increasingly guided by free market prices, has occurred on a top-down, controlled model of development. ${ }^{47}$ Movement toward a more decentralized "bottom-up" mode of change, marked in the securities regulation area by high quality disclosure, investor empowerment to change underperforming management teams, and court adjudication under a rule of law approach, can be expected to be unwelcomed. Empowered investors would act through voting shares, or selling shares into tender offers or by initiating suit against

47. It is claimed by Professor Yasheng Huang that much growth at the beginning of liberalization appears to have been resulted from the spontaneous action of farmers and rural residence when simply allowed access to land and ability to contract (Huang 2007, 2008). But certainly with respect to the SOEs and the stock markets post-1990, the whole story is one of designed top-down development. 
insiders or other controllers of the firms in which they make investments. These means of action, however, involve instrumentalities (boards, courts, shareholder meetings) that, in a bottom-up development regime, would not formally be a part of or agents of the Chinese Communist Party. Thus, it is reasonable to expect that substantial reform of the corporate governance of firms listed on Chinese securities markets will not occur until there is a pressing developmental reason for the leadership to force such change. Certainly those pressures are not sufficient at this time to occasion real change.

The existing limitations of the Chinese securities markets can be expected to be remedied over time - and the securities markets can be expected to play a more productive role in the Chinese economy - if, but only if, the leadership of the country wants Chinese securities markets to assume a more important role. This conclusion reflects the fundamental nature of these markets. Unlike securities markets in New York, London, or Amsterdam, the Chinese markets were designed and created by government principally to serve government purposes. Like their existence, their future depends upon the judgments to be made by the country's political leadership. Trying to predict choices those leaders may make is fraught with risk of miscalculation. It seems certain that even absent improvement in the practical ability of equity investors to protect their own economic interests, Chinese securities markets will for a period continue to grow as the PRC economy grows. Thus these markets will continue to satisfy the limited economic role that they have thus far been permitted to play. But they will not serve the larger important economic functions of efficient capital allocation, nor the useful role of signaling, incenting, or disciplining corporate management. But Rome, we have often been reminded, was not built in a day; nor have the great Redwood trees of California reached their enormous size and beauty in just sixty years.

\section{References}

Aharony, J. J. Lee, and T. J. Wong. 2000. "Financial Packaging of IPO Firms in China." Journal of Accounting Research 38:103-26.

Allen, Franklin, Jun Qian, and Meijun Qian. 2005. "Law, Finance and Economic Growth in China." Journal of Financial Economics 77:57-116.

Allen, William T., Reinier Kraakman, and Guhan Subramanian. 2012. Commentaries and Cases on Law of Business Organization, 4th ed. Wolters Klur Law \& Business Publishers.

Agrawal, Ashwini K. 2009. "The Impact of Investor Protection Laws on Corporate Policy: Evidence from the Blue Sky Laws.” http://pages.stern.nyu.edu/ sternfin /aagrawal/public_html/blue_sky.pdf. 
Bebchuk, Lucian. 1987. "The Pressure to Tender: An Analysis and a Proposed Remedy." Delaware Journal of Corporate Law 12:911-49.

Bebchuk, Lucian A., John C. Coates IV, and Guhan Subramanian. 2002. "The Powerful Antitakeover Force of Staggered Boards: Further Findings and a Reply to Symposium Participants." Stanford Law Review 55:885-917.

Bebchuk, Lucian, and Alma Cohen. 2005. "The Costs of Entrenched Boards." Journal of Financial Economics 78:409-33.

Blanchard, O., and P. Aghion. 1996. "On Insider Privatization.” European Economic Review 40:759-66.

Caijing Magazine. 2009. "188 Companies Apply to Liston GEM." October 26. http:// english.caijing.com.cn/2009-10-26/110294620.html.

Chang, E., and S. Wong. 2004. "Political Control and Performance in China's Listed Firms." Journal of Comparative Economics 32 (4): 617-36.

Che, Jiahua, and Yingyi Qian. 1996. "Insecure Property Rights and Government Ownership of Firms." http://papers.ssrn.com/sol3/papers.cfm?abstract_id=5201.

Chen, Dong-Hua, Joseph P. H. Fan, and T. J. Wong. 2004. "The Board Structure, Government Influence, and the Performance of Listed Companies in China."

Chen, Gongmeng, Michael Firth, and Liping Xu. 2009. "Does the Type of Ownership Control Matter? Evidence from China's Listed Companies.” Journal of Banking and Finance 33: (1): 171-81.

Chinese Securities Regulatory Commission (CSRC). 2003. Principles of Corporate Governance for Listed Companies. http://www.csrc.gov.cn.

2005. Guidelines for Equity-Based Compensation.

2008. China Capital Markets Development Report. China Financial Publishing House.

Clarke, Donald C. 2008. "The Ecology of Corporate Governance in China.” George Washington Law School Working Paper. http://ssrn.com/abstract=1245803.

Coffee, John C., Jr. 2007. "Law and the Market: The Impact of Enforcement." Columbia Law and Economics Working Paper No. 304. March 7. http://ssrn.com labstract $=967482$.

Deng, Jiong. 2005. "Building an Investor-Friendly Shareholder Derivative Lawsuit System in China." Harvard International Law Review 46:347, 365, n. 108.

Easterbrook, Frank, and Daniel Fischel. 1989. "The Corporate Contract." Columbia Law Review 89 (7): 1416-48.

. 1991. The Economic Structure of Corporate Law. Cambridge, MA: Harvard University Press.

Fan, Joseph P. H., T. J. Wong, and Tianyu Zhang. 2007. "Politically Connected CEOs, Corporate Governance and Post-IPO Performance of China's Partially Privitized Firms." Journal of Financial Economics 84:330-57.

Francis, Bill B., Iftekhar Hasan, and Xian Sun. 2009. "Political Connections and the Process of Going Public: Evidence from China." Journal of International Money and Finance 28 (4): 696-719.

Firth, Michael, Gong-meng Chen, Daniel Ning Gao, and Oliver M. Rui. 2005. "Is China's Securities Regulatory Agency a Toothless Tiger? Evidence from Enforcement Actions." January. http://ssrn.com/abstract=711107.

Fogel, Robert W. 2006. "Why China is Likely to Achieve its Growth Objectives." NBER Working Paper no. 12122. Cambridge, MA: National Bureau of Economic Research, March.

Gordon, Roger H., and Wei Li. 2013. "Provincial and Local Governments in China: Fiscal Institutions and Government Behavior." In Capitalizing China, edited by Joseph P. H. Fan and Randall Morck, 337-69. Chicago: University of Chicago Press. 
Green, Stephen. 2003. "Better than a Casino: Some Good News from the Front Lines of China's Capital Market Reform." China Project Working Paper. http:// papers.ssrn.com/sol3/papers.cfm?abstract_id=431200.

Handal, Kenneth. 1972. "The Commercial Paper Market and the Securities Laws." University of Chicago Law Review 39:362-402.

Hellman, Joel, and Mark Schankerman. 2000. "Intervention Corruption and Capture: The Nexus between Enterprises and the State." Economics of Transition 8:545-76.

Howson, Nickolas. 2009. "China's Restructured Commercial Banks: Nomenclature Accountability Serving Corporate Governance Reform?” In China's Emerging Financial Markets, edited by Martha Avery, Min Zhu, and Jinqing Cai, 123-64. Singapore: John Wiley \& Sons.

$\mathrm{Hu}$, Runfeng, Zhe Cheng, and Tao Fu. 2006. "Zhonghang Shenqiu Zhibang Zai Bao Piaoju An [Another Bank of China Shenqiu Branch Receipts Case Explodes]." Caijing Magazine 161:40-41.

Huang, Hui. 2008. "The New Takeover Regulation in China: Evolution and Enhancement." The International Lawyer 42:153.

Huang, Yasheng. 2007. "The Rural Roots of China's Miracle." Financial Times, October 21. http://www.ftchinese.com/story.php?lang=en\&storyid=001014907.

- 2008. Capitalism with Chinese Characteristics. Cambridge: Cambridge University Press,

Johnston, Robert. 1968. "The Rebirth of Commercial Paper." Monthly Review Federal Reserve Bank of San Francisco: 137-42.

Kahan, Marcel, and Edward B. Rock. 2002. "How I Learned to Stop Worrying and Love the Pill: Adaptive Responses to Takeover Law." University of Chicago Law Review 69 (3): 871-915.

Li, Larry, Tony Naughton, and Martin Hovey. 2008. "A Review of Corporate Governance in China." http://ssrn.com/abstract $=1233070$.

Liebman, Benjamin, and Curtis Milhaupt. 2008. "Reputational Sanctions in China's Securities Market." Columbia Law Review 108: 929, 958.

Lipton, Martin. 1997. "Poison Pill Update." M\&A Law Jul./Aug., 3.

Morck, Randall, Bernard Yeung, and Wayne Yu. 2000. "The Information Content of Stock Markets: Why Do Emerging Markets Have Synchronous Stock Price Movements." Journal of Finance and Economy 58: 215.

McKinsey Global Institute. 2006. Putting China's Capital to Work: The Value of Financial System Reform. May. http://www.mckinsey.com/mgi/publications /china_capital/index.asp, at 62.

. 2009. Global Capital Markets: Entering a New Era. September. http://www .mckinsey.com/locations/swiss/news_publications/pdf/Global_Capital_Markets _Sept_2009.pdf, at 27.

Pistor, Katharina. 2013. "The Governance of China's Finance.” In Capitalizing China, edited by Joseph P. H. Fan and Randall Morck, 35-60. Chicago: University of Chicago Press.

Shleifer, A., and L. Summers. 1988. "Breach of Trust in Hostile Takeovers." In Corporate Takeovers: Causes and Consequences, edited by A. Auerbach, 33-68. Chicago: University of Chicago Press.

Shanghai Stock Exchange. Zhongguo Gongsi Zhili Baogao (2008): Shangshi Gongsi Toumingdu yu Xinxi Pilu (2008 PRC Corporate Governance Report: Transparency of Listed Companies and Information Disclosure). http://www.sse.com.cn/cs/zhs /xxfw/research/special/special20081120.pdf.

Shanghai Stock Exchange. Monthly Statistic Report. http://www.sse.com.cn/ sseportal/ps/zhs/yjcb/sztjyb.shtml. 
Shen, Han. 2008. "A Comparative Study of Insider Trading Regulation Enforcement in the U.S. and China." Journal of Business and Securities Law 9:41-74.

Shen, Yan, Minggao Shen, Zhong Xu, and Ying Bai. 2009. "Bank Size and Smalland Medium-sized Enterprise (SME) Lending: Evidence from China." World Development 37: 800.

Shenzhen Stock Exchange. 2002. Zhongwai Xinxi Pilu Zhidu Ji Shiji Xiaoguo Bijiao Yanjiu (Comparative Study of the Information Disclosure System and Effects). http://www.cninfo.com.cn/finalpage/2002-04-23/590499.PDF.

Shenzhen Stock Exchange. 2008. "Key Issues relating to the Review of Public Offering Applications and An Analysis of Rejected Applications." http://www.szse.cn /main/images/2008/11/10/20081110152952164.pdf.

Tam, Kit. 2002. "Ethical Issues in the Evolution of Corporate Governance in China." Journal of Business Ethics 37: 305, 307.

Tan, Wentao. 2006. "History of China's Stock Markets.” In China's Financial Markets: An Insider's Guide to How the Markets Work, edited by Salih N. Neftci and Michelle Yuan Menager-Xu, 215-36. Burlington, MA: Academic Press.

Thurow, Lester, Ning Zhou, and Yunshi Wang. 2003. "The PRC's Real Economic Growth Rate." www.oes.org/pdf/presentations/lesterthurow/pdf.

Tuan, Jason, JinXin Zhang, Jason Hsu, and Qiusheng Zhang. 2007. Merger Arbitrage Profitability in China. http://www.ssrn.com/abstract=992650.

US Securities and Exchange Commission (SEC). 2005. Annual Report of US Securities and Exchange Commission, 7. http://www.sec.gov/about/secpar/secpar2005 .pdf\#sec1.

- 2006. Annual Report of US Securities and Exchange Commission, 8. http:// www.sec.gov/about/secpar/secpar2006.pdf\#sec1.

- 2007. Annual Report of US Securities and Exchange Commission, 25. http:// www.sec.gov/about/secpar/secpar2007.pdf\#sec1.

- 2008. Annual Report of US Securities and Exchange Commission, 12. http:// www.sec.gov/about/secpar/secpar2008.pdf\#sec1.

Wei Yu. 2009. "Party Control in China's Listed Firms." http://ssrn.com/abstract $=1326205$.

Wong, S. M. L., S. Opper, and R. Hu. 2004. "Shareholder Structure, Depoliticalization, and Firm Performance: Lessons from China's Listed Firms." Economics of Transition 12:29-66.

World Federation of Exchanges (WFE). 2009. Annual Report and Statistics 2007. Accessed April 1, 2009. http://www.world-exchanges.org/files/file/2007\%20WFE $\% 20$ Annual\%20Report.pdf, at 74 .

Xie, Baishan, Xuelai Dai, and Lan Xu. 2003. "Comparative Study of US and Chinese Securities Markets." In International Comparison of Securities Markets 3-4, edited by Baisan Xie, 535-50. Beijing: Tsinghua University Press.

Xie, Zhihong, and Mingtian Chen. 2001. "Guhong Paisheng Susong Zai Sikao [Rethinking Shareholder Derivative Suits]." Fuijian ZhengFa Guanli Ganbu Xueyuan Xue bao [Journal of the Fuijian Politcal-Leghal Administrative Cadre Institute 4: 24.

Xiu Shi-yu, and Liu Chang. 2008. "The Degree of IPO Underpricing in China." Journal of Modern Accounting and Auditing 4 (4): 32-36.

Zhang, Wenkui. 2002. "The Role of China's Securities Market in SOE Reform and Private Sector Development.” http://www.tcf.or.jp/data/20020307-08_Wengkui ZZhang.pdf.

Zhang Yujun. 2005. "Developing the SME Board and Encourage the Growth of SMEs." http://www.sme.gov.cn/web/assembly/action/browsePage.do?channel ID $=1129097785944 \&$ contentID $=1130306361557$. 
Zhou, Weimin, Zhongguo Zheng, and Jian Hui. 1998. "A Critique of the Shortcomings of the CSRC's Temporary Rules on Prohibiting Entry to the Securities Market.” FaXue [Legal Science] 4:60-61.

\section{Comment Qiao Liu}

The current chapter by William T. Allen and Han Shen (henceforth AS) assesses the Chinese securities markets from aspects that are of central concern in developing these markets: the positioning of securities markets in the national system of finance, their size and scope, their evolution pattern, the regulatory environment, and the corporate governance of the Chinese listed firms. Allen and Shen carefully document and discuss at length several key characteristics of the Chinese securities markets, including the share segmentation system, the state sector centric market design, concentrated ownership structures, low level of liquidity and poor pricing efficiency, limited market access for the private sector, the contradictory mandates of the CSRC (China Securities Regulatory Commission, the watchdog of the Chinese capital markets), and the control-based corporate governance mechanisms used by the listed firms. Allen and Shen characterize the Chinese securities markets as top-down markets designed by the government to ensure the state purposes. As such, these markets deem to be politically driven and cannot exert significant economic effects on the Chinese economy. The authors also conclude that the further development of China's securities markets hinges on whether the Chinese government is willing to give up the control over these markets and allow them to serve basic economic roles rather than the state purposes.

This chapter offers many structured details to illustrate the top-down nature of the Chinese securities markets. Such illustrations contribute to the understanding of the approaches used by the Chinese government to develop capital markets and assist interested readers, especially those with little knowledge about China, to understand the working of the Chinese securities markets.

I have two principal concerns about the thesis of this chapter. First, as I will show later, I believe that top-down is an oversimplified characterization of the Chinese securities markets. Second, AS overemphasize the state sector in their analysis and fail to consider the quick surge of the private sector.

Qiao Liu is professor of finance and of economics at Guanghua School of Management, Peking University.

For acknowledgments, sources of research support, and disclosure of the author's material financial relationships, if any, please see http://www.nber.org/chapters/c12461.ack. 